\title{
New species of Acraspisoides Hill \& Winterton and Bonjeania Irwin \& Lyneborg (Diptera: Therevidae: Agapophytinae), with the description of a new genus
}

\author{
SHAUN L. WINTERTON \\ Queensland Department of Primary Industries \& Fisheries, Indooroopilly, Queensland, Australia. \\ E-mail:wintertonshaun@gmail.com
}

\begin{abstract}
The stiletto fly subfamily Agapophytinae is diverse and species rich in Australasia, with numerous undescribed species. A new species of Acraspisoides Hill \& Winterton, A. monticola sp. nov., is described from females collected in montane localities in eastern Australia. Eight new species of Bonjeania Irwin \& Lyneborg are also described, raising the total number of known species to 18 . Five new species, B. affinis sp. nov., B. apluda sp. nov., B. bapsis sp. nov., B. webbi $\mathbf{s p .}$ nov. and $B$. zwicki sp. nov., all have a distinctive, forward-protruding head with antennae on a raised tubercle. Two other new species, $B$. argentea $\mathbf{s p . ~ n o v . ~ a n d ~ B . ~ j e f f e r i e s i ~ s p . ~ n o v . , ~ a r e ~ c l o s e l y ~ r e l a t e d ~ t o ~} B$. segnis (White), with very similar shaped male genitalia and body shape. An eighth species, B. lambkinae sp. nov., is closely related to B. clamosis Winterton \& Skevington. Bonjeania and Acraspisoides are diagnosed and revised keys to species presented. An unusual new therevid, Vomerina humbug gen. et sp. nov., is also described and figured based on a series of males from New South Wales. This new genus likely represents the sister taxon to Bonjeania.
\end{abstract}

Key words: Therevidae, Diptera, stiletto fly, Asiloidea

\section{Introduction}

The stiletto fly subfamily Agapophytinae is largely endemic to Australasia and comprises at least 11 genera with over 300 described and undescribed species (Winterton et al. 2001). This subfamily presently includes the genera Acatopygia Kröber, Acraspisa Kröber, Acraspisoides Hill \& Winterton, Acupalpa Kröber, Agapophytus Guérin, Belonalys Kröber, Bonjeania Irwin \& Lyneborg, Laxotela Winterton \& Irwin, Parapsilocephala Kröber, Patanothrix Winterton and Pipinnipons Winterton, although this number may increase substantially once the Taenogera genus-group (sensu Winterton et al. 1999b) is included in Agapophytinae as suggested by Winterton (2006).

Acraspisoides was originally described for a single species, A. helviarta Hill \& Winterton, which was placed as sister to the rest of Agapophytinae sensu stricto based on morphological and molecular evidence (Hill \& Winterton 2004). A new species, A. monticola sp. nov., is described from high elevation localities in Queensland and New South Wales.

The genus Lonchorhynchus White was originally described to accommodate three Tasmanian therevids, L. segnis White, L. actuosa White and Anabarhynchus nitidifrons Macquart (White 1915, Mann 1929). Lonchorhynchus was subsequently found to be preoccupied (i.e. Wiman 1910) and Bonjeania was proposed as a replacement name in the catalogue of Australasian and Oceanian Therevidae (Irwin \& Lyneborg 1989). Bonjeania was revised recently by Winterton et al. (2000), expanding the number of described species to 10 . The genus was also subsequently diagnosed in a phylogenetic context using both molecular and morphological data by Winterton et al. (2001). Since then, eight additional species from Australia have been identified in col- 
lections and are described and figured herein. Five new species, B. affinis sp. nov., B. apluda sp. nov., B. bapsis sp. nov., $B$. webbi sp. nov. and $B$. zwicki sp. nov., belong to a species group also containing $B$. actuosa and B. orphne Winterton \& Skevington based on the shape of the head and body. Two other additional species, $B$. argentea sp. nov. and $B$. jefferiesi sp. nov., are closely related to $B$. segnis based on similarities in body and male genitalia shape. An eighth species, B. lambkinae sp. nov., is closely related to B. clamosis Winterton \& Skevington and based on the phylogenetic analysis by Winterton et al. (2000), is typical of more derived Bonjeania species, with a rounded head and greatly elongated male genitalia. Considering the number of new species described herein, revised diagnoses and keys to species of both Bonjeania and Acraspisoides are included. Vomerina humbug gen. et sp. nov. is also described and figured from New South Wales, and is an unusual, putative sister taxon to Bonjeania.

\section{Materials and methods}

Terminology for wing venation follows McAlpine et al. (1981) and Irwin \& Lyneborg (1981), and genitalic morphology as modified by Winterton et al. (1999a, b) and Winterton (2006). As discussed in Winterton (2006), this paper also follows Hauser \& Irwin (2003) in the use of the term pubescence sensu Nichols (1989) instead of pruinescence to describe microtrichia covering the adult body.

Genitalia were macerated in $10 \% \mathrm{KOH}$ at room temperature for one day to remove soft tissue, then rinsed in distilled water and dilute glacial acetic acid, and dissected in $80 \%$ ethanol. Female reproductive organs were stained with a saturated solution of Chlorazol Black in $40 \%$ ethanol. Genitalia preparations were placed in glycerine in a genitalia vial mounted on the pin beneath the specimen.

Types are located in the Queensland Department of Primary Industries and Fisheries (QDPI) and Queensland Museum (QMBA) in Brisbane, Australian Museum, Sydney (AMSA), and the Australian National Insect Collection (ANIC) in Canberra, Australia, Michael Irwin Insect Collection (MEIC) (to be deposited in the California Academy of Sciences, San Francisco, USA) and the Illinois Natural History Survey (INHS), Champaign, Illinois, USA. Other collections listed include the Mike G.Jefferies Collection (to be deposited in ANIC) and Greg Daniels collection (GDCB) (to be deposited in AMSA).

Numbers quoted with individual specimens as MEI \#\#\#\#\# are unique identifiers in the therevid database MANDALA and are attached to each specimen as a yellow label (Kampmeier et al. 2004).

\section{Taxonomy}

\section{Acraspisoides Hill \& Winterton}

Acraspisoides Hill \& Winterton, 2004: 4. Type species: Acraspisoides helviarta Hill \& Winterton, 2004: 4, by original designation.

Diagnosis. Body length: Male 10.0-10.5 mm; female 8-12.0 mm.

Antennae positioned low on frons, slightly shorter than head length; flagellum slightly longer than combined length of scape and pedicel; scape short and cylindrical; 2-3 poorly defined rows of postocular setae in both male and female; pleuron with longitudinal stripe of velutum; velutum patches present on hind and fore femora, patch on hind femur relatively small; hind femur distinctly longer than fore and mid femora; anteroventral, subapical seta absent on hind femur; wing with dark banding, cell $m_{3}$ closed; gonocoxites without velutum patches; medial atrium between gonocoxites absent; dorsal apodeme of parameral sheath ' $T$ 'shaped; large ventral bulb present basally on distiphallus, projecting externally of genitalic capsule between gonocoxites; anterior process of female tergite 8 narrow; three spermathecae; spermathecal sac small, simple, 
spherical in shape.

Comments. Acraspisoides is very similar in appearance to Acraspisa, although it is much larger in size, has multiple rows of postocular setae in the male, and lacks an acuminate scutellum. Leg and abdominal colouration is variable in both species. Unique to species of this genus is the relatively small patch of velutum on posteroventral surface of the hind femur. In all other agapophytine s.s. genera, this patch is much more elongate. Phylogenetic analysis by Hill \& Winterton (2004) placed Acraspisoides as the sister genus of all other Agapophytinae (sensu Winterton et al. 2001). Although males are unknown for A. monticola sp. nov., the two species of Acraspisoides are easy to differentiate based on female body colouration.

Included species. Acraspisoides helviarta Hill \& Winterton, A. monticola sp. nov.

\section{Key to Acraspisoides species}

1. Thorax mostly yellow; abdomen at least with basal segments yellow laterally. monticola sp. nov.

- Thorax and abdomen almost completely black ..... helviarta Hill \& Winterton

\section{Acraspisoides monticola sp. nov.}

Holotype female, AUSTRALIA: NEW SOUTH WALES: Kosciuszko NP, 1.7 km ENE Thredbo, Malaise over narrow stream in wide grassy creek bed, 2-11.i.2004, 1380m, C.L. Lambkin, N.T. Starick, 36³0'07'S, 148¹9’02”'E (MEI 165147) (ANIC).

Paratypes, AUSTRALIA: NEW SOUTH WALES: female, same data as holotype (MEI 165148) (QDPI). QUEENSLAND: female, Mt. Glorious, Aug.-Sept.1996, 27²0.08'S, 15246.05'E, 650 m, S.L. Winterton, Malaise (MEI 165149) (QDPI).

Diagnosis. Thorax uniform yellow or with dark suffusion on scutum; abdomen yellow to black, basal segments yellow at least laterally, segment 6 always black; terminalia yellow.

Description. Female Body length: 7.5-10.0 mm.

Head. Dark, overlain with dense, grey pubescence; longer than high in profile; frons flat or slightly convex, much wider than ocellar tubercle at narrowest point, antennae positioned low on frons; frons and face projecting anteroventrally; frontal pubescence admixed with sparsely distributed, short, dark setae; ocellar tubercle flattened; occiput convex, black, overlain with grey pubescence; multiple rows of black postocular setae; gena with long, pale setae ventrally; palp and labellum dark yellow with scattered dark setae; antenna yellow, shorter than head; dark setae of various lengths on scape and pedicel, lacking on medial surface; flagellum ovate, longer than scape and pedicel length combined.

Thorax. Dark yellow to yellow-brown, glossy; scutum sometimes with dark suffusion, overlain with sparse, grey pubescence admixed with numerous short, dark setae; scutellum covered with dense, matte black pubescence on anterior surface, yellow around margin and on posterior surface; scutal macrosetae (bristles) black; pleuron, sternum and coxae dark yellow to light brown, glossy; distinct longitudinal stripe of silver velutum on proepisternum, katepisternum, katepimeron, and meron; short pale setae on proepisternum, katepisternum, anepisternum and coxae; setae on katatergite pale, sometimes admixed with dark setae; legs light to dark brown, dark brown on posterior surface of fore and hind femora; hind tibia dark brown; wing hyaline with distinct black banding pattern; venation dark; haltere stem black, knob white; scutal chaetotaxy (pairs): notopleural (np), 3; supra-alar (sa), 1; postalar (pa), 1; dorsocentral (dc), 1-2; scutellar (sc), 1.

Abdomen. Glossy yellow to black-brown; always yellow laterally on segments 1-4; segment 6 always dark brown to black; scattered dark setae on each segment, terminalia yellow.

Genitalia. Not dissected. Similar externally to females of A. helviarta. 
Male. Unknown

Etymology. The specific epithet is derived from Latin: montis, mountain, and -cola, dweller, referring to collections of this species only in montane areas.

Comments. Acraspisoides monticola sp. nov. is known only from female specimens from montane localities in New South Wales and Queensland. This species is distinctive by its dark yellow and black body colouration.

\section{Bonjeania Irwin \& Lyneborg}

Lonchorhynchus White, 1915: 33 (preoccupied by Wiman, 1910); Mann, 1929: 44. Type species: Anabarhychus nitidifrons Macquart 1850: 405 (101) by original designation.

Bonjeania Irwin \& Lyneborg, 1989: 356 (nom. nov. for Lonchorhynchus White); Winterton et al. 2000: 297 (revision); Winterton et al. 2001: 203 (diagnosis).

Diagnosis. Antenna positioned low on frons; antenna shorter than head length; head shape in profile either rounded or with frons and face protruding anteriorly; male occiput concave to convex with single row (rarely multiple rows) of postocular setae; female occiput convex with multiple, poorly defined rows of postocular setae; wing cell $m_{3}$ closed; wing hyaline to dark infuscate, never strongly banded; wing infuscation usually sexually dimorphic; anteroventral subapical seta absent on hind femur; fore and hind femora with velutum patches; all femora of approximate equal length; posterior margin of abdominal tergites 1-4 often with thickened band of velutum orientated anteriorly; medial atrium present; gonocoxite with velutum (often on membrane bordering or covering medial atrium); gonocoxal apodemes usually greatly elongate, often greater than four times length of gonocoxite, sometimes shorter than gonocoxite; distiphallus usually extremely long and thin; dorsal apodeme of parameral sheath poorly sclerotised, sometimes reduced or absent; ejaculatory apodeme and lateral ejaculatory apodeme greatly enlarged; single spermatheca; spermathecal sac simple, shape spherical or near so (rarely reduced).

Comments. Winterton et al. (2000) revised Bonjeania describing seven new species in addition to the three previously described by Macquart (1850) and White (1915). Winterton et al. (2001) subsequently diagnosed the genus in a phylogenetic context using molecular and morphological data, placing Bonjeania in the Parapsilocephala clade with Patanothrix, Acatopyiga and Parapsilocephala. The single spermatheca in the female, unique amongst Therevidae and most Asiloidea, is diagnostic for the genus. The greatly elongate aedeagus and gonocoxal apodemes in the male genitalia are also characteristic for the genus, although not present in some species such as B. segnis, B. jefferiesi sp. nov. and B. argentea sp. nov. Bonjeania is distributed throughout all of Australia. The number of species contained in the genus Bonjeania is increased considerably with the inclusion of those described herein, therefore a revised key to species modified after Winterton et al. (2000) is presented to aid in identification.

Included species. Bonjeania actuosa (White), B. affinis sp. nov., B. angelikae Winterton \& Skevington, B. apluda sp. nov., B. argentea sp. nov., B. bapsis sp. nov., B. clamosis Winterton \& Skevington, B. dynastis Winterton \& Skevington, B. flavofemoralis Winterton \& Skevington, B. irwinae Winterton \& Skevington, $B$. jefferiesi sp. nov., B. lambkinae sp. nov., B. nitidifrons (Macquart), B. orphne Winterton \& Skevington, $B$. segnis (White), B. trilineata Winterton \& Skevington, B. webbi sp. nov., B. zwicki sp. nov.

\section{Key to Bonjeania species}

1. Head shape in profile round or slightly higher than long (see Winterton et al. 2000: fig. 1); antennae not 
produced anteriorly, or only slightly raised on tubercle on lower frons; anterior margin of wing not infuscate.

- Head shape in profile projecting anteriorly, longer than high (Figs 4A and 7A); antennae produced anteriorly on protruding lower frons and face; wing infuscate along anterior margin (sometimes also smoky infuscate throughout wing)....

2. Pleuron and anterior abdominal segments with distinct, white-silver stripe of pubescence (Fig. 1)..... zwicki sp. nov.

Pleuron and anterior abdominal segments without stripe of pubescence 3.

3. Scutum mostly black, covered with white, scale-like setae apluda sp. nov.

- Scutum completely orange (sometimes with dark medial stripe), without white, scale-like setae ............. 4.

4. Pleuron uniformly black; anterior margin of wing dark infuscate....... bapsis sp. nov.

- Pleuron orange on dorsal half, ventral half black; anterior margin of wing orange-yellow.. webbi sp. nov.

5. Median occipital sclerite glossy black; gonocoxal apodeme and distiphallus greatly elongate with ejaculatory apodeme relatively narrow in profile (see Winterton et al. 2000: fig. 10A).

- Median occipital sclerite pubescent; height of ejaculatory apodeme almost equal to length (Winterton $e t$ al. 2000: fig. 7E), or gonocoxal apodeme and aedeagus not greatly elongate, barely extending anteriorly beyond genitalic capsule (Figs 3F-G, 5F-G)

6. All femora entirely yellow; pubescence on scutum entirely white dorsolaterally and posteriorly, two dorsocentral white spots at transverse suture, poorly defined dorsocentral white stripes extending from posterior of scutum anteriorly 1/2 way to transverse suture; katepisternum silver pubescent on all but anterodorsal edge where glossy black flavofemoralis Winterton \& Skevington.

- Mid femur yellow basally; pubescence on scutum restricted to small, white, posterolateral and anterolateral patches; katepisternum black, very sparsely silver pubescent, appearing bare but not glossy.

irwinae Winterton \& Skevington.

7. Frons entirely silver pubescent except for elliptical glossy brown, medial patch above antennal insertions; scutum patterned as in Winterton et al. (2000: fig. 5B), white setae covering scutum; mid femur with single ventromedial bristle; hind femur with 3 ventromedial macrosetae; postpronotal lobe entirely silver pubescent, covered with white setae. trilineata Winterton \& Skevington.

- None of these characters present 8.

8. Frons mostly covered with elongate setae; katatergite glossy brown; male frons wider than or equal to width of ocellar tubercle (except $B$. argentea sp. nov.).

- Frons with few, relatively short setae; katatergite with at least some pubescence; males with ocellar tubercle wider than narrowest point of frons .

9. Legs entirely bright yellow; antennae bright yellow; scutum and scutellum glossy black; wing venation yellow orphne Winterton \& Skevington.

- Legs not as above; antennae dark brown; scutum and scutellum pubescent; wing venation dark. 10.

10. Coxae black, overlain with silver pubescence; aedeagus and gonocoxal apodeme relatively short, barely extending anteriorly from genitalic capsule; ejaculatory apodeme not greatly elongate (Figs $2 \mathrm{E}, 3 \mathrm{~F}, 5 \mathrm{~F}$ ).. 11.

- Coxae orange-yellow; aedeagus and gonocoxal apodemes greatly elongate, extending anteriorly a long distance into abdominal cavity; ejaculatory apodeme greatly elongate (see Winterton et al. 2000: figs 6DF)... actuosa (White).

11. Femora bright orange; scutum glossy black with white, pubescent, dorsocentral stripes anteriorly, pubescence filled between stripes posteriorly to form quadrangular shape; pleuron glossy black with dense stripe of silver pubescence; occiput convex dorsally in both sexes.

affinis sp. nov.

- Femora dark brown or black; scutum dark, overlain with black or grey-brown mottled pubescence; dorsocentral stripes only faint at best; sparse, grey-silver pubescence on entire lower half of pleuron; male 
occiput concave along dorsal margin (female convex)

12. Scutum overlain entirely with matte, black pubescence.... segnis (White).

- Scutum overlain with brown-grey pubescence, often mottled or with faint grey dorsocentral stripes .... 13.

13. Scutum brown mottled pubescent; male abdomen brown laterally, with silver velutum. argentea sp. nov.

- Scutum overlain with brown pubescence with grey dorsocentral stripes; abdomen brown pubescent medially, silver velutum absent. jefferiesi sp. nov.

14. Scutum with broad matte black stripe between dorsocentral setae (see Winterton et al. 2000: fig. 5A); spermathecal sac reduced nitidifrons (Macquart).

- Scutum without matte black stripe; spermathecal sac not reduced 15.

15. Scutum with matte black pubescence posteriorly in both sexes; male scutum also mostly brown pubescent anteriorly, with narrow, grey dorsocentral stripes; female scutum also brown pubescent anteriorly but with metallic grey patch of pubescence medially, matte black pubescence present anteriorly as dorsocentral stripes; male hypandrium with posteriorly directed lobes laterally, adorned with strong, dark and pale setae (Fig. 6B-C) lambkinae sp. nov.

- Scutum not patterned as above; male hypandrium without lobes 16.

16. Body length greater than $12 \mathrm{~mm}$; katepisternum densely silver pubescent on posterior $1 / 2$, very sparsely pubescent on anterior 1/2 so appearing brown but not glossy; frons wrinkled (male unknown).....

dynastis Winterton \& Skevington.

- Body length less than $8.5 \mathrm{~mm}$; katepisternum silver pubescent on all but anterodorsal edge where glossy dark brown; frons smooth

17. Femora black; tarsi of fore leg dilated (see Winterton et al. 2000: fig. 5I); dorsum of scutum appearing black, sparsely brown pubescent clamosis Winterton \& Skevington.

- Mid femur yellow on distal 2/3, brown proximally; tarsi of fore leg and mid leg approximately equal in diameter (see Winterton et al. 2000: fig. 5J); dorsum of scutum densely brown pubescent.

angelikae Winterton \& Skevington.

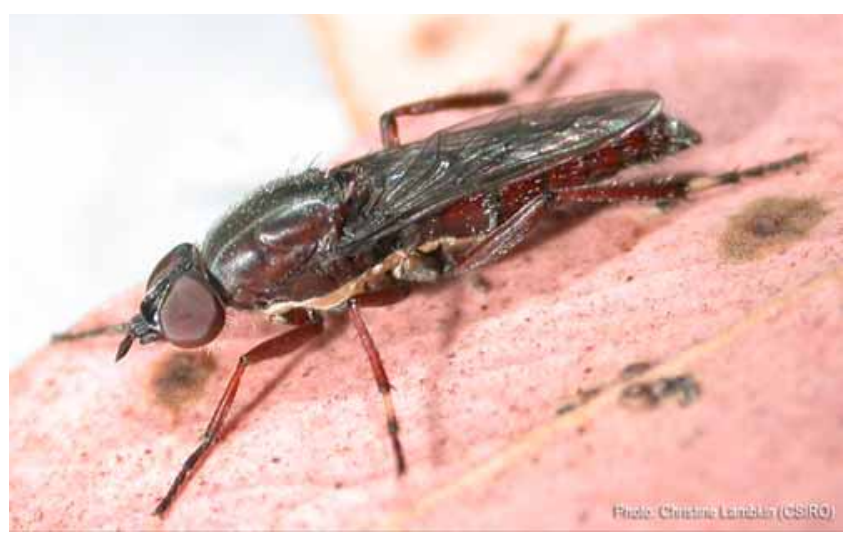

FIGURE 1. Bonjeania zwicki sp. nov., holotype male habitus. Photo: Christine L. Lambkin, CSIRO.

\section{Bonjeania affinis sp. nov.}

(Figures 2A-F)

Holotype male, AUSTRALIA: TASMANIA: 9 km SE Miena, 10.i.1992, 2660', M.E. Irwin, B.J. Irwin (MEI 26098) (ANIC).

Paratypes, AUSTRALIA: TASMANIA: 2 males, female, same data as holotype (MEI 26100, 26102) (ANIC), (MEI 26097) (QDPI); male, female, same data as holotype, D.W. Webb (MEI 26099) (INHS), (MEI 26101) (MEIC). 


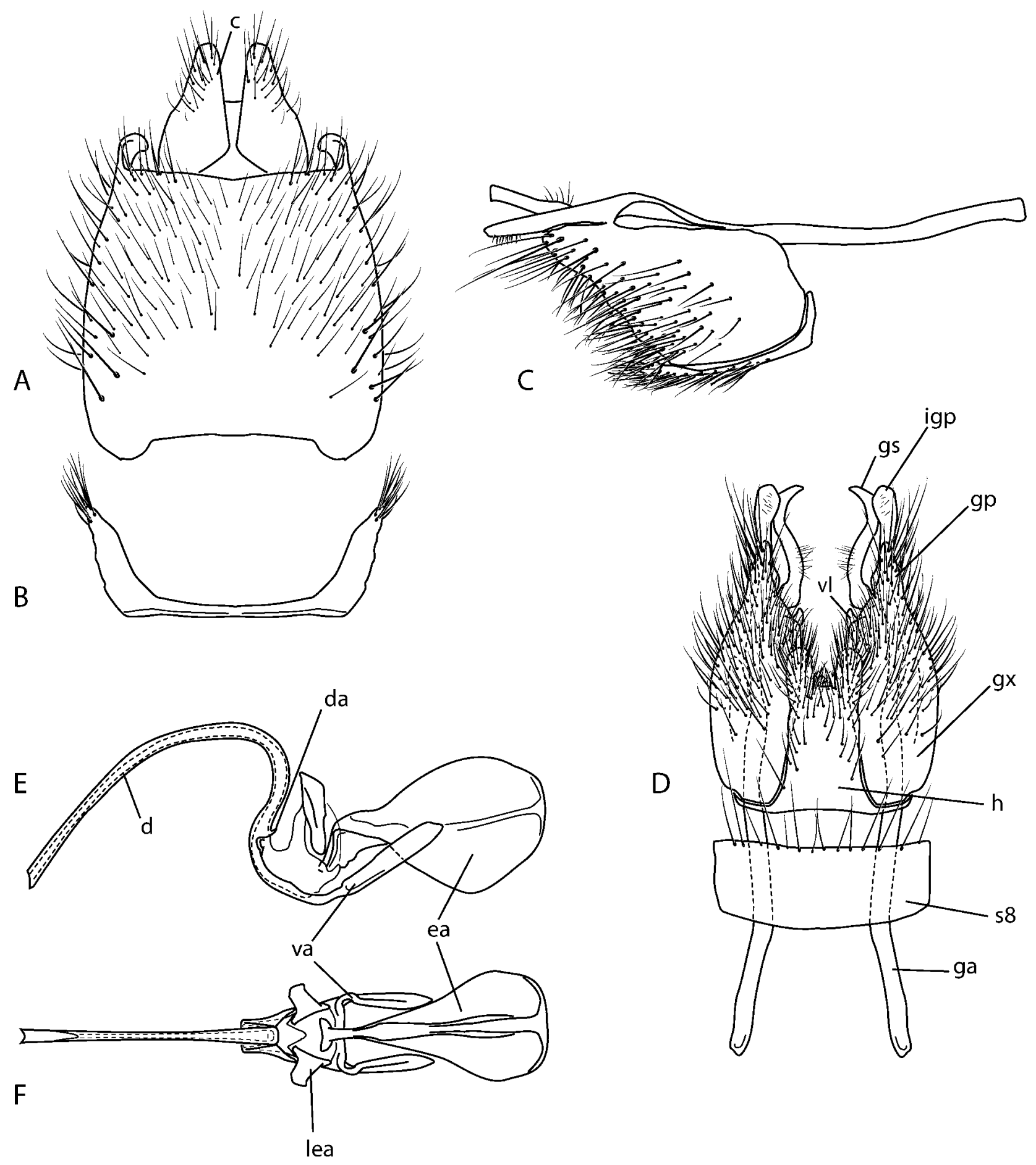

FIGURE 2. Bonjeania affinis sp. nov., male genitalia: A, epandrium, dorsal view; B, tergite 8, dorsal view; C, gonocoxite, lateral view; D, gonocoxites and sternite 8, ventral view; E, aedeagus, lateral view; F, same, dorsal view. Abbreviations: $c$, cercus; $d$, distiphallus; $e a$, ejaculatory apodeme; $g a$, gonocoxal apodeme; $g p$, gonocoxal process; $g s$, gonostylus; $g x$, gonocoxite; $h$, hypandrium; igp, inner gonocoxal process; lea, lateral ejaculatory apodeme; $s 8$, sternite 8 ; $v a$, ventral apodeme of parameral sheath; $v l$, ventral lobe. Scale line $=0.5 \mathrm{~mm}$.

Diagnosis. Frons wider than ocellar tubercle in both sexes; male with multiple poorly defined rows of postocular setae dorsally; legs orange; coxae dark; scutum glossy black with white pubescent stripes; male genitalia not greatly elongate; epandrium elongate; tergite 8 emarginate medially; gonocoxal apodeme only slightly longer than gonocoxite length; hypandrium with posterolateral lobes overlain with dense setae; dis- 
tiphallus recurved dorsally.

Description. Male. Body length: 7.5-9.0 mm.

Head. Frons wider than ocellar tubercle at narrowest point, antennal base positioned low on frons; upper frons slightly raised, rounded; lower frons slightly rugose, flattened, lower frons and face scarcely protruding anteriorly, frons and face glossy black, short, dark setae sparsely distributed on frons, setae longer on upper frons, silver pubescence laterally on frons along margin of eye, and on face beside and below antennal base; ocellar tubercle slightly raised, black with short dark setae; occiput convex, glossy black, overlain with sparse grey pubescence medially, multiple poorly-defined rows of relatively long, black postocular setae dorsally; gena black, overlain with silver-white pubescence admixed with long, white setae; palp and labellum brown with scattered dark setae; antenna orange-brown, overlain with brown grey pubescence, shorter than head, scattered, dark setae on scape, pedicel and base of flagellum.

Thorax. Glossy black; scutum overlain with two dorsocentral stripes of silver-white pubescence, coalescent posteriorly as a single broad medial stripe ending on scutellum, postpronotal lobe and notopleural area overlain with silver-white pubescence, scutum sparsely covered with short, dark setae; scutal macrosetae black; silver stripe of velutum on pleuron running through proepisternum, proepimeron, dorsal portion of katepisternum, and meron; coxae glossy dark-brown, pale setae on anterolateral surfaces; legs orange with sparse, pale setae; wing hyaline with translucent brown infuscation in cells posterior cubital (cu-p), third medial $\left(m_{3}\right)$, discal $(d)$, basal portion of second+third radial cell $\left(r_{2+3}\right)$, and portions of basal radial $(b r)$ and basal medial ( $b m$ ) cells; venation brown; haltere stem brown, knob white; scutal chaetotaxy (pairs): np, 3-5; sa, 1-2; pa, 1-2; dc, 4-7; sc, 1 .

Abdomen. Glossy black-brown with scattered pale setae, setae on terminalia pale; tergite 1 with silverwhite pubescence laterally, brown pubescence dorsally on segments $1-5$, intersegmental membrane of segments 2-4 white; terminalia dark.

Male genitalia. Epandrium arched with lateral margins extending ventrally (Fig. 2A), posterolateral corners extending posteriorly as narrow, apically spatulate processes; cercus quadrangular in shape, narrowed apically; tergite 8 medially emarginate (Fig. 2B); gonocoxal process much shorter than gonostylus (Fig. 2C); inner gonocoxal process equal length to gonostylus; gonocoxal apodeme $c a$. equal length of gonocoxite; ventral lobe small, projecting dorsomedially; medial atrium small; hypandrium separate from gonocoxites, quadrangular, bilobed on posterior margin (Fig. 2D); sternite 8 quadrangular; aedeagus relatively short, distiphallus recurved dorsally proximal to ejaculatory apodeme (Figs 2E-F); lateral ejaculatory apodeme and ejaculatory apodeme enlarged.

Female. Body length: 7.0-9.0 mm.

Similar to male except: Frons slightly wider than male frons; shorter setae on thorax and abdomen.

Female genitalia. Spermathecal sac elongate, cordate basally, single lobed; spermathecal sac duct relatively long, without sclerotised band; single membranous, round spermatheca; spermathecal duct joined to spermathecal sac duct proximal to base of spermathecal sac; accessory gland elongate, relatively small.

Etymology. The specific epithet is derived from Latin: affinis, related to; referring to the external similarity of this species to B. actuosa.

Comments. Bonjeania affinis sp. nov. is very similar in external appearance to B. actuosa but the male genitalia of this species are quite different as the genitalic apodemes are not greatly enlarged. This species is known from a single series from NW Tasmania.

\section{Bonjeania apluda sp. nov.}

Holotype female, AUSTRALIA: NEW SOUTH WALES: Warrumbungle NP, Wombelong Ck. at woolshed, 27.xii.1987, M.E. Irwin (MEI 26194) (ANIC). 
Paratypes, AUSTRALIA: NEW SOUTH WALES: female, Mt. Kaputar NP, Upper Bullawa Ck., 19.i.1994, M.E. Irwin, D.K. Yeates, Malaise trap (MEI 26195) (MEIC). QUEENSLAND: Carnarvon NP, Mt. Moffatt Section, W Branch Maranoa R. (site 16), 2508'22”S, 14750'37’E, 660m amsl, 25.xi.1995, M.E. Irwin, S.D. Gaimari, ex. 9m Fock's Malaise trap (MEI 31179) (MEIC); female, Carnarvon NP, Mt. Moffatt Section, nr Mt. Moffatt, 19-23.i.1998, S.L. Winterton, J.\&A. Skevington, Malaise trap (MEI 91442) (UQIC); female, Carnarvon NP, Mt. Moffatt Section, Mt. Moffatt Rd., 2504’01”S, 14800'50”E, 29.xi.1997, J.H. Skevington, C.L. Lambkin, Malaise trap (MEI 91440) (QDPI).

Diagnosis. Head protruding anteriorly with antennae on frontal tubercle; female with single row of postocular setae; scutum dark, overlain with distinctive white, scale-like setae, post-pronotal lobes and scutellum orange; wing costal margin dark infuscate.

Description. Female. Body length: $7.0-8.0 \mathrm{~mm}$.

Head. Frons flat, rugose, much wider than ocellar tubercle at narrowest point, antennal base positioned low on frons; lower frons and face protruding anteriorly; frons and face glossy black to dark brown; short, pale setae sparsely distributed on frons; two rounded patches of silver pubescence laterally on frons along margin of eye, single patch on face extending from margin of eye towards antennal base; ocellar tubercle barely raised, glossy black, sparsely overlain with short, dark setae, slightly spatulate setae (black and white admixed) on posterior margin; occiput concave, black, overlain with grey pubescence; single row of relatively short, black postocular setae; gena black with black setae, narrow strip of silver-white pubescence along margin of eye; palp and labellum brown with scattered dark setae; antenna orange-brown, slightly shorter than head, dark setae on scape and pedicel; scape glossy, glabrous on lateral surface; flagellum with scattered short dark setae.

Thorax. Scutum glossy black, finely rugose, covered with sparse, lanceolate to spatulate white scales, postpronotal lobe, postalar callus and anterolateral portion of scutum orange; scutellum dark orange-brown; scutal macrosetae black; pleuron, sternum and coxae bright orange to brown, glossy; anepisternum and katepisternum black to brown; dark setae on anepisternum, katatergite and coxae; legs orange; femora with short dark setae; tibia slightly darkened apically, tarsi cream coloured, individual tarsomeres light brown distally; wing translucent brown infuscate anteriorly, fading to clear hyaline posteriorly; venation dark; haltere brown; scutal chaetotaxy (pairs): np, 5-7; sa, 1 [rarely 2]; pa, 1 [rarely 2]; dc, 0; sc, 1.

Abdomen. Glossy black, brown ventrally, uniform scattered dark setae, brown pubescence dorsally on tergites $1-3$.

Female genitalia. Spermathecal sac rounded, single lobe; spermathecal sac duct relatively long, without sclerotised band, single membranous, round spermatheca; spermathecal duct joined to spermathecal sac duct proximal to base of spermathecal sac; accessory gland elongate, relatively small.

Male. Unknown.

Etymology. The specific epithet is derived from Latin: apluda, chaff, bran; referring to the white scales on the scutum.

Comments. Bonjeania apluda sp. nov. is closely related to B. webbi sp. nov. and B. bapsis sp. nov. The black body colour and white scales are diagnostic for this species. This species is only known from female specimens and is distributed throughout central Queensland and New South Wales, inland from the coast.

\section{Bonjeania argentea sp. nov.}

(Figure 3)

Holotype male, AUSTRALIA: VICTORIA: Fiddlers Creek, Cann R[iver]. Road, 37¹7'45’S, 149¹2'47’E, 25.xi.1995, M.G. Jefferies (MEI 109808) (ANIC).

Paratypes, AUSTRALIA: VICTORIA: male, 2 females, same data as holotype (MEI 109611-2 [pinned 
together], 109814) (ANIC). AUSTRALIAN CAPITAL TERRITORY: 3 males, female, Barton, 15.x.1981, M.G. Jefferies (MEI 109609-10 [pinned together]) (QDPI), (MEI 109811-12) (ANIC); male, Barton, 4.xi.1981, M.G. Jefferies (MEI 109806) (ANIC); male, female, Capital Hill, 13.x.1981, M.G. Jefferies (MEI 109605-6 [pinned together]) (ANIC); NEW SOUTH WALES: male, Gilgandra Flora Reserve, 8 km NE Gilgandra, 14.viii.1983, M.E. Irwin (MEI 130013) (MEIC).

Other material examined. 3 males, 2 females, bushland east of Gilmour, 5-15.xi.2003 [multiple dates in this range], D.J. Ferguson, Malaise trap (ANIC29 15813, 15686, 15812, 15687, 17779) (ANIC).

Diagnosis. Frons only slightly protruding, male frons slightly wider than ocellar tubercle at narrowest point; male abdomen with silver velutum; male genitalia with epandrium very short, much wider than long; aedeagus and gonocoxal apodemes not greatly elongate, gonocoxal apodemes about equal length to gonocoxites; distiphallus short, slightly curved ventrally; hypandrium relatively small.

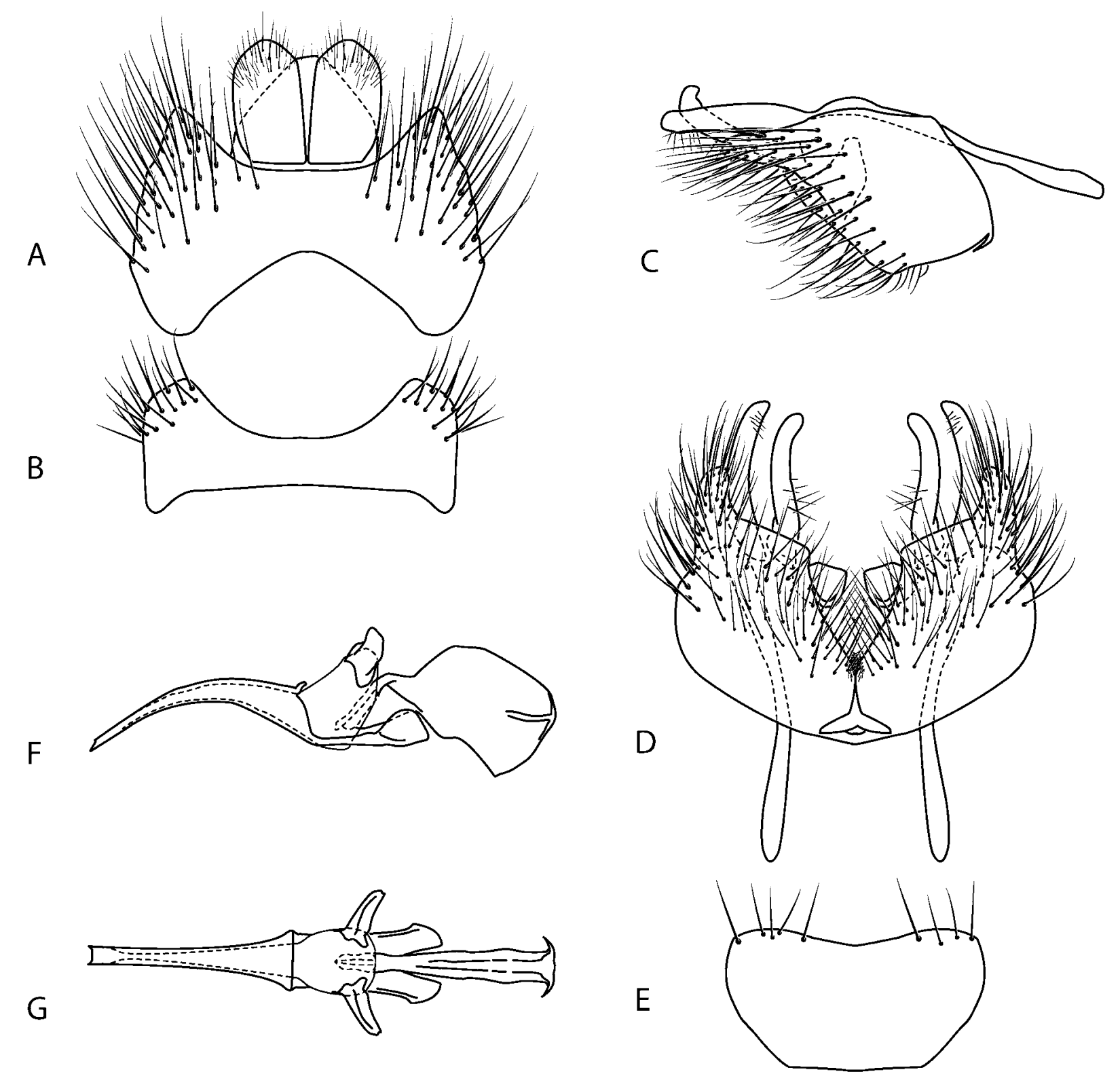

FIGURE 3. Bonjeania argentea sp. nov., male genitalia: A, epandrium, dorsal view; B, tergite 8, dorsal view; C, gonocoxite, lateral view; D, gonocoxites, ventral view; E, sternite 8, ventral view; F, aedeagus, lateral view; G, same, dorsal view. Scale line $=0.5 \mathrm{~mm}$. 
Description. Male. Body length: $7.0 \mathrm{~mm}$.

Head. Frons wider than ocellar tubercle at narrowest point; antennal base positioned low on frons; frons flat, slightly rugose; frons and face only slightly protruding, glossy black with sparsely distributed, elongate setae; dark setae on upper frons, pale setae laterally on lower frons and face, silver pubescence medially on upper frons, laterally along margin of eye, and on face beside and below antennal base; ocellar tubercle slightly raised, black with elongate, dark setae; occiput convex, black, overlain with grey pubescence, single row of relatively long, black, postocular setae dorsally; gena black, overlain with dense, silver-white pubescence admixed with long, white setae; palp and labellum brown with scattered dark and pale setae; antenna shorter than head, brown, overlain with brown-grey pubescence; numerous elongate setae on scape, pedicel, and base of flagellum; setae pale ventrally, darker dorsally on scape and pedicel.

Thorax. Glossy black; scutum overlain with brown pubescence, pale grey to white pubescent laterally and posteriorly, uniformly admixed with short, dark setae; scutal macrosetae black; scutellum overlain with olivaceous pubescence, paler laterally; pleuron and coxae covered with dense, silver pubescence except on anepisternum, anepimeron and katatergite; elongate, pale setae on anepisternum, katepisternum, katatergite and coxae; legs dark brown; tibia and basitarsi dark yellow basally; elongate, pale setae on femora; wing hyaline with translucent brown infuscation distally in cells $b m, d$ and basally in radial cell $r_{5}$; venation brown; haltere stem brown, knob white; scutal chaetotaxy (pairs): np, 3-4; sa, 1-2; pa, 1; dc, 3-6; sc, 1.

Abdomen. Matte dark brown with dark yellow laterally and ventrally on each segment, covered with scattered, pale setae, setae elongate laterally; tergite 1 with silver-white pubescence laterally, segments $2-7$ covered with dense, silver velutum dorsally; intersegmental membrane of segments 2-4 white; setae on terminalia pale; terminalia dark.

Male genitalia. Genitalia similar shape to B. segnis and B. jefferiesi sp. nov. Epandrium very short, medially emarginated (Fig. 3A); cercus slightly elongate; tergite 8 medially emarginate (Fig. 3B); gonocoxal process shorter than gonostylus (Figs 3C-D); inner gonocoxal process equal length to gonostylus; gonocoxal apodeme shorter than gonocoxites; medial atrium present, pubescence only a small medial patch; hypandrium small, triangular; sternite 8 broadly trapezoidal (Fig. 3E); aedeagus relatively short, distiphallus curved dorsally along length (Fig. 3F-G); dorsal apodeme of parameral sheath absent; lateral ejaculatory apodeme and ejaculatory apodeme enlarged; arms of ventral apodeme of aedeagal sheath relatively short, rounded.

Female. Body length: 7.0-9.0 mm.

Similar to male except: Frons only slightly wider, abdomen wholly black, shorter setae on thorax and abdomen, and silver abdominal velutum lacking.

Female genitalia. Spermathecal sac elongate, cordate basally, single lobe, spermathecal sac duct relatively long, without sclerotised band, single membranous, round spermatheca; spermathecal duct joined to spermathecal sac duct proximal to base of spermathecal sac; accessory gland elongate, relatively small.

Etymology. The specific epithet is derived from Latin: argentum, silver; referring to the silver velutum on the male abdomen.

Comments. Bonjeania argentea sp. nov. is closely related to B. jefferiesi sp. nov. and B. segnis and is very similar in appearance. This species is known from New South Wales and the Australian Capital Territory.

\section{Bonjeania bapsis sp. nov.}

(Figure 4)

Holotype male, AUSTRALIA: QUEENSLAND: Carnarvon NP, Mt. Moffatt Section, W Branch Maranoa R. (site 16), 2508’22”S, 14750’37’E, 660m amsl, 25.xi.1995, M.E. Irwin, S.D. Gaimari, ex. 9m Fock's Malaise trap (MEI 31180) (ANIC).

Paratypes, AUSTRALIA: QUEENSLAND: female, Carnarvon NP, Mt. Moffatt Section, Top Moffatt

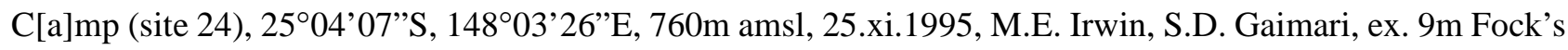


Malaise trap (MEI 31316) (ANIC); 2 females, Carnarvon NP, Mt. Moffatt Section, Marlong Cr. [creek], nr

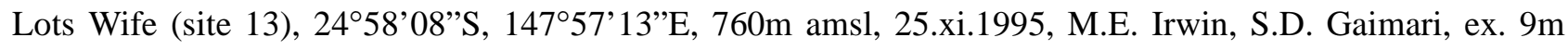
Fock's Malaise trap (MEI 31389-90) (ANIC); female, Carnarvon NP, Mt. Moffatt Section, Mt. Moffatt Rd.,

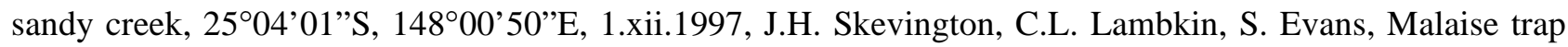
(MEI 91445) (UQIC); female, Carnarvon NP, Mt. Moffatt Section, Mt. Moffatt Rd., dry creek, 2503'52”S, 14801'00”E, 2.xii.1997, J.H. Skevington, C.L. Lambkin, S. Evans, Malaise trap (MEI 91444) (UQIC); female, Carnarvon NP, Mt. Moffatt Section, 2503'15”S, 14753'12’E, 27-28.xi.1997, J.H. Skevington, C.L. Lambkin, Malaise trap (MEI 91446) (UQIC); male, State Forest 50, nr Expedition Range NP, 7-10.iv.2001,

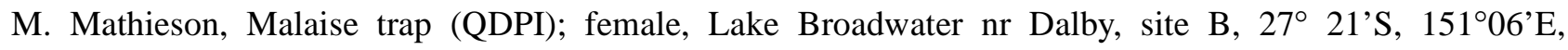
28.ix.1986, G.\&A. Daniels (MEI 26196) (AMSA). NEW SOUTH WALES: 2 females, Goonoo State Forest, 23km SW Mendooran, 14.i.1994, M.E. Irwin, D.K. Yeates (MEI 26197-8) (MEIC).

Diagnosis. Lower frons and face protruding anteriorly; wing costal margin dark infuscate; scutum bright orange; head, pleuron and abdomen black; male genitalia with epandrium much shorter along midline than width; aedeagus and gonocoxal apodemes greatly elongate; ejaculatory apodemes enlarged; hypandrium narrow, band-like.

Description. Male. Body length: 6.0-8.0 mm.

Head. Frons only slightly narrower than ocellar tubercle at narrowest point, antennal base positioned low on frons; upper frons flat, lower frons and face protruding anteriorly (Fig. 4A); frons and face glossy black; short, dark setae sparsely distributed on frons; three elongate patches of silver pubescence laterally on frons along margin of eye, two patches on face beside and below antennal base; ocellar tubercle slightly raised, black with sparse, grey pubescence posteriorly, admixed with short dark setae; occiput concave, black, overlain with grey pubescence; single row of relatively short, black, postocular setae; gena black with long, black setae, silver-white pubescence along margin of eye; palp and labellum brown with scattered, dark setae; antenna dark brown, approximately equal length to head; dark setae on scape and pedicel, flagellum with small patches of short dark setae dorsally and ventrally; flagellum wider and longer than scape and pedicel; scape glossy; pedicel and flagellum overlain with grey pubescence.

Thorax. Scutum and scutellum bright orange; presutural area of scutum with broad, black, medial stripe ending at transverse suture, occasionally with a pair of small dark spots at posterior end of stripe; scutum sparsely covered with short, pale setae; scutal macrosetae black; pleuron, sternum and coxae glossy black, short, dark setae on anepisternum, katepisternum, katatergite and coxae; legs black-brown with sparse, dark setae on femora; approximate mid-point of tibia with yellow-cream coloured band; tarsi yellow-cream, individual tarsomeres brown distally; wing translucent, brown infuscate anteriorly, fading to clear hyaline posteriorly; venation dark; haltere brown; scutal chaetotaxy (pairs): np, 4-5; sa, 1; pa, 2; dc, 1-2 [slender]; sc, 1.

Abdomen. Black-brown with scattered, dark setae laterally, setae on terminalia pale; brown pubescence dorsally on segments $1-5$.

Male genitalia. Epandrium much shorter than wide, deeply emarginate on both posterior and anterior margin (Fig. 4B); cercus rounded; tergite 8 only slightly medially emarginate (Fig. 4C); gonocoxal process slightly shorter than gonostylus (Figs 4D-E); inner gonocoxal process equal length to gonostylus; gonocoxal apodeme $c a$. 3x length of gonocoxite; hypandrium reduced, band-like, leaving large, membranous medial atrium; ventral lobe reflexed dorsomedially, narrow apically; sternite 8 broadly trapezoidal (Fig. 4E); aedeagus elongate, distiphallus recurved dorsally proximal to ejaculatory apodeme (Fig. 4D); lateral ejaculatory apodeme relatively small; ejaculatory apodeme enlarged; arms of ventral apodeme of aedeagal sheath relatively broad in profile.

Female. Body length: 5.5-8.0 mm.

Similar to male except: Frons much wider than ocellar tubercle at narrowest point; frons with two lateral spots of silver pubescence along eye margin; scutum without black stripe; thorax and abdomen with shorter darker setae covering. 

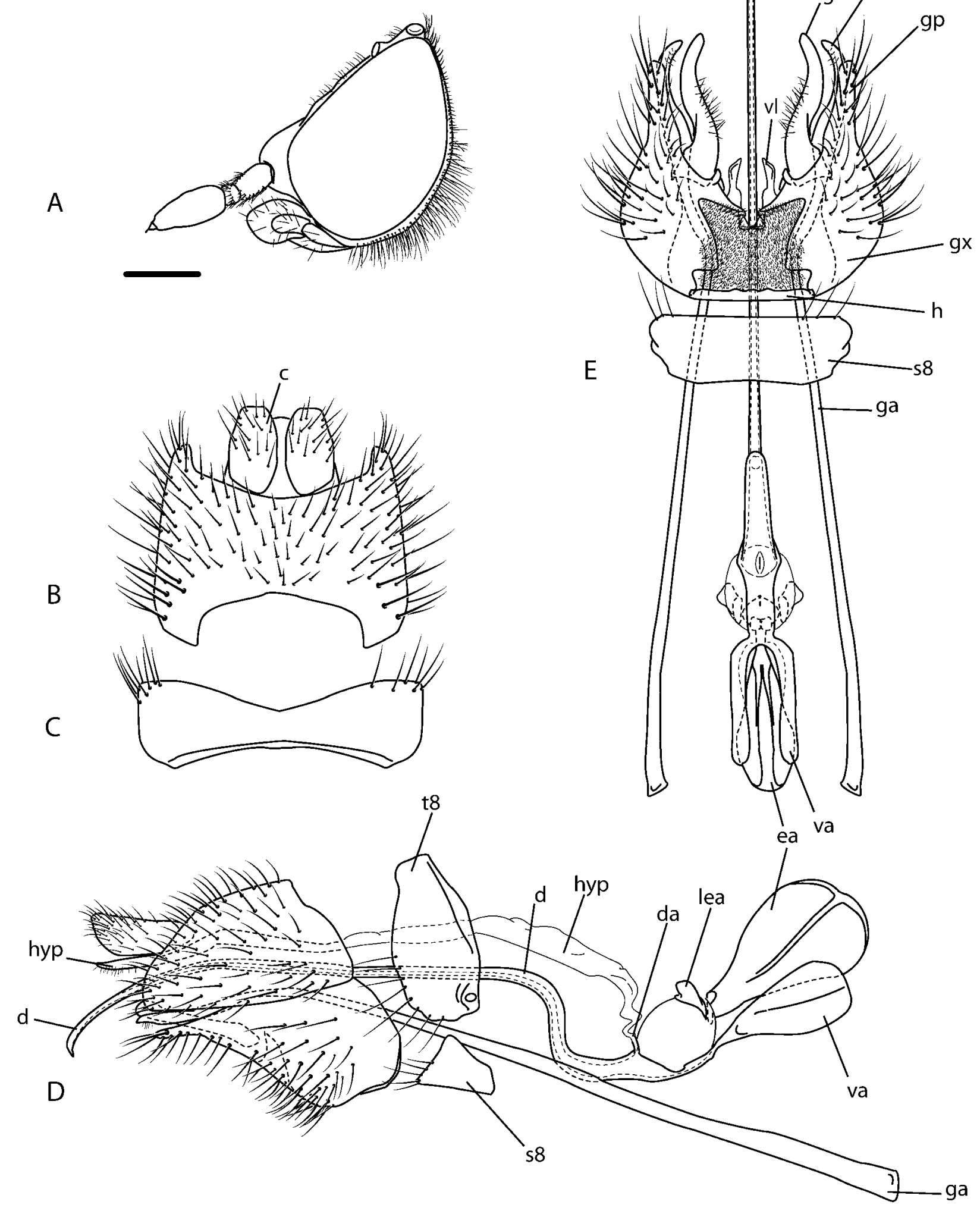

FIGURE 4. Bonjeania bapsis sp. nov.: A, male head, lateral; male genitalia: B, epandrium, dorsal view; C, tergite 8, dorsal view; $\mathrm{D}$, genitalia, lateral view; $\mathrm{E}$, same, ventral view with epandrium removed. Abbreviations: $c$, cercus; $d$, distiphallus; $d a$, dorsal apodeme of parameral sheath; $e a$, ejaculatory apodeme; ga, gonocoxal apodeme; $g p$, gonocoxal process; $g s$, gonostylus; $g x$, gonocoxite; $h$, hypandrium; hyp, hypoproct; igp, inner gonocoxal process; lea, lateral ejaculatory apodeme; $s 8$, sternite 8 ; $t 8$, tergite 8 ; $v a$, ventral apodeme of parameral sheath; $v l$, ventral lobe. Scale line= $0.5 \mathrm{~mm}$. 
Female genitalia. Spermathecal sac rounded, single lobe, spermathecal sac duct relatively long, without sclerotised band, single membranous, round spermatheca; spermathecal duct joined to spermathecal sac duct proximal to base of spermathecal sac; accessory gland elongate, relatively small.

Etymology. The specific epithet is derived from Greek: bapsis, a dipping, dyeing; referring to the bright orange coloured dorsum of the thorax that appears to be coloured artificially.

Comments. Bonjeania bapsis sp. nov. is most closely related to B. webbi sp. nov. This species is distributed throughout central and southern Queensland to central New South Wales, inland from the coast.

\section{Bonjeania jefferiesi sp. nov. \\ (Figure 5)}

Holotype male, AUSTRALIA: AUSTRALIAN CAPITAL TERRITORY: Mt. Ginini, 1700m, 4.i.1982, M.G. Jefferies (MEI 109594) (ANIC).

Paratypes, AUSTRALIA: AUSTRALIAN CAPITAL TERRITORY: 2 males, same data as holotype (MEI 109595, 109598) (ANIC); male, Picadilly Circus, 35²1'S, 148²7’'E, 6.xii.1994, M.G. Jefferies (MEI 109603) (QDPI).

Diagnosis. Frons only slightly protruding, male frons slightly wider than ocellar tubercle at narrowest point; male abdomen without silver velutum; male genitalia with epandrium short, wider than long; aedeagus and gonocoxal apodemes not greatly elongate, gonocoxal apodemes about equal length to gonocoxites; distiphallus short, slightly curved ventrally; medial atrium relatively small.

Description. Male. Body length: $7.0 \mathrm{~mm}$.

Head. Frons width slightly wider than ocellar tubercle at narrowest point; antennal base positioned low on frons; frons flat, rugose; frons and face only slightly protruding anteriorly, glossy black with elongate setae sparsely distributed; black setae on upper frons, pale setae laterally on lower frons and face; sparse silver pubescence on frons, denser laterally along margin of eye and on face beside and below antennal base; ocellar tubercle slightly raised, black with elongate, dark setae; occiput flat to slightly convex, black, overlain with grey pubescence; single row of relatively long, black, postocular setae dorsally; gena black, overlain with dense, silver-white pubescence admixed with long, white setae; palp and labellum brown with scattered, pale setae; antenna slightly shorter than head, brown, overlain with brown-grey pubescence; flagellum tinged with orange-brown pubescence; numerous elongate setae on scape, pedicel, and base of flagellum; setae pale ventrally, darker setae dorsally on scape and pedicel.

Thorax. Glossy black; scutum overlain with brown pubescence, pale grey to white pubescent laterally and posteriorly, pale, dorsocentral stripe; uniformly admixed with short, dark setae; scutal macrosetae black; scutellum overlain with olivaceous pubescence, pale laterally, admixed with dark, elongate setae; pleuron and coxae covered with dense, silver pubescence except on medial region of anepisternum, anepimeron and katatergite; elongate pale setae on anepisternum (few), katepisternum, katatergite and coxae; legs dark brown, tibia, basitarsi and hind femora paler basally; dark, slightly elongate setae ventrally on femora; wing hyaline with translucent brown infuscation distally in cells $b m, d$ and basally in cell $r_{5}$; venation brown; haltere brown; scutal chaetotaxy (pairs): np, 3-5; sa, 1; pa, 1; dc, 3-6; sc, 1 (+1-2 smaller macrosetae).

Abdomen. Uniform matte dark brown; dorsomedially overlain with olivaceous green to brown pubescence admixed with short, dark setae; tergites 1-4 with silver-white pubescence admixed with elongate, pale setae laterodorsally; intersegmental membrane of segments 2-4 white, brown medially; terminalia dark with pale setae.

Male genitalia. Genitalia similar shape to $B$. segnis and B. argentea sp. nov. Epandrium short, medially emarginate (Fig. 5A); cercus slightly elongate; tergite 8 medially emarginate (Fig. 5B); gonocoxal process shorter than gonostylus (Figs 5C-D); inner gonocoxal process equal length to gonostylus; gonocoxal apo- 
deme shorter than gonocoxites; medial atrium very small; hypandrium triangular, fused to gonocoxite laterally; ventral lobe small, angular; sternite 8 broadly ovate to quadrangular (Fig. 5E); aedeagus relatively short, distiphallus only slightly curved dorsally along length (Figs 5F-G); dorsal apodeme of parameral sheath absent; lateral ejaculatory apodeme and ejaculatory apodeme enlarged; arms of ventral apodeme of aedeagal sheath relatively short, narrow.

Female. Similar in size and colouration to male.

Etymology. The specific epithet is a patronym in honour of Michael G. Jefferies, the collector of the specimens.

Comments. Bonjeania jefferiesi sp. nov. is closely related to B. argentea sp. nov. and B. segnis and is very similar in appearance to $B$. segnis. Bonjeania species typically have wing cell $m_{3}$ closed, yet the type specimen of B. jefferiesi sp. nov. has wing cell $m_{3}$ barely open in the left wing and closed in the right. Such variation is rare but does occur in other therevids. This species is known from the Australian Capital Territory.

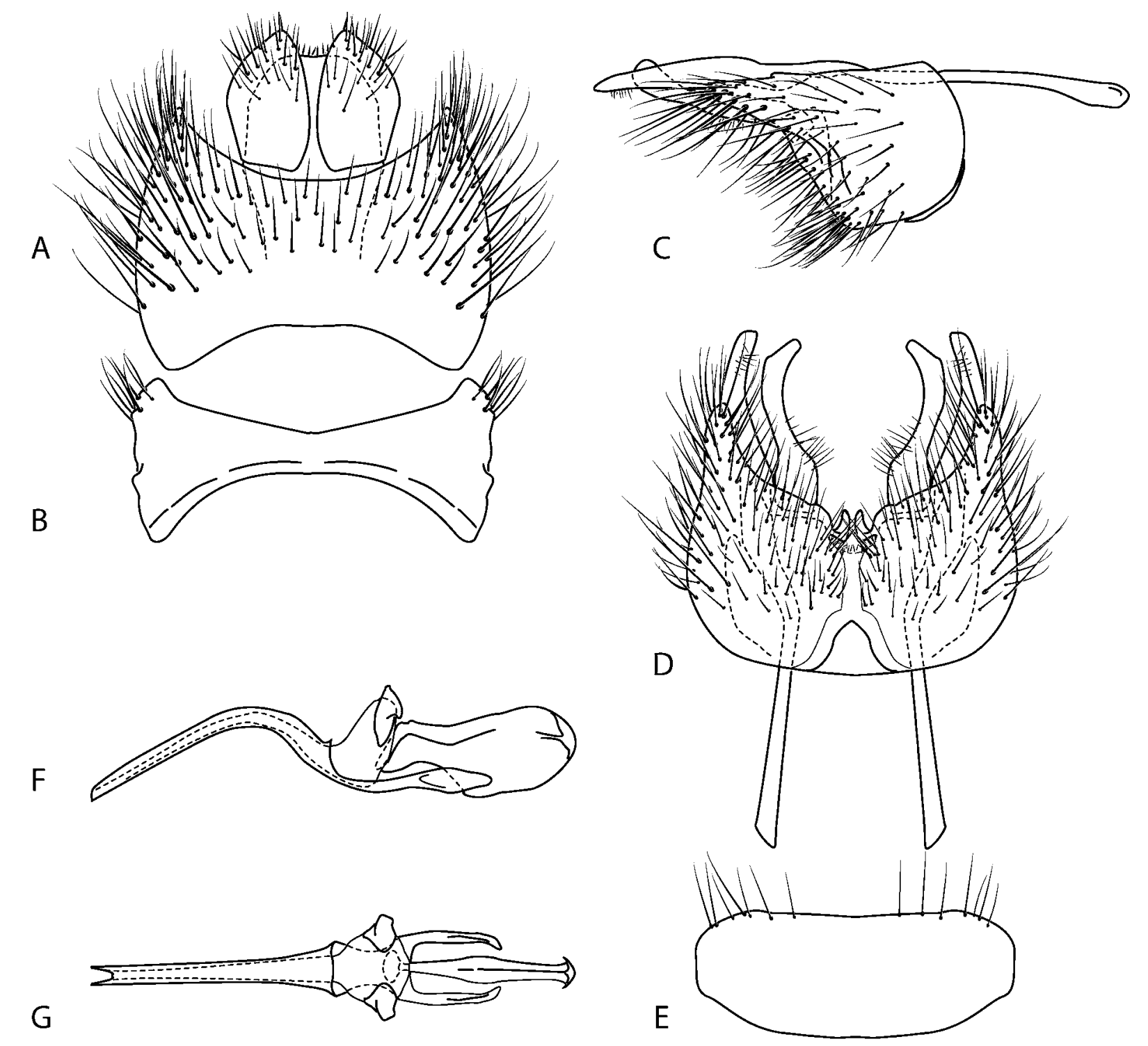

FIGURE 5. Bonjeania jefferiesi sp. nov., male genitalia: A, epandrium, dorsal view; B, tergite 8, dorsal view; C, gonocoxite, lateral view; D, gonocoxites, ventral view; E, sternite 8, ventral view; F, aedeagus, lateral view; G, same, dorsal view. Scale line $=0.5 \mathrm{~mm}$. 


\section{Bonjeania lambkinae sp. nov.}

(Figure 6)

Holotype male, AUSTRALIA: NEW SOUTH WALES: Tinderry Nature Reserve, Bluebell link track, 13.2 km ENE Michelago, grassy clearing in snow-gums, Malaise, 29.i.2004-26.ii.2005, 1200 m, C.L. Lambkin, N. Starick, 3540’26”'S, 149¹8’09”'E (MEI 165135) (ANIC).

Other material examined. AUSTRALIA: NEW SOUTH WALES: female, Tinderry Nature Reserve, Intersection East Tinderry \& Horse Flat Fire Trail, 13.3 km ENE Michelago, Malaise over dry gully, 26.ii.19.iii.2005, 1065 m, C.L. Lambkin, N. Starick, 3540’51’S, 149¹8’26”E (MEI 165136) (QMBA).

Diagnosis. Head rounded, not protruding anteriorly; frons with small tubercle above antennal bases; scutellum and posterior section of scutum overlain with matte black pubescence; male velutum plaques on posterior margin of abdominal tergites 2-4 (similar to B. clamosis); male genitalia with greatly elongate gonocoxal apodemes and aedeagus; ejaculatory apodemes greatly enlarged; epandrium bulbous anterolaterally; hypandrium with posteriorly projecting, lateral processes covered with dark setae.

Description. Male. Body length: $9.0 \mathrm{~mm}$.

Head. Frons width equal to width of ocellar tubercle at narrowest point; antennal base positioned low on frons; frons flat, very small tubercle above antennal base, tubercle vertically striated medially; frons and face glossy black; upper frons overlain with brown-silver pubescence sparsely admixed with fine, black setae; frons with silver pubescence around antennal base and as triangular patch along eye margin immediately dorsal of tubercle, pubescence extending ventrally along eye margin; face overlain with silver pubescence; ocellar tubercle slightly raised, black, overlain with bronze pubescence admixed with dark setae, setae longer posteriorly; occiput concave, densely overlain with grey pubescence, bronze dorsally; single row of black, postocular setae dorsally; gena black, overlain with dense, silver-white pubescence admixed with long, white setae; palp and labellum brown with scattered, pale setae; antenna shorter than head, brown; flagellum overlain with sparse, silver-brown pubescence; dark setae on scape, pedicel, and base of flagellum.

Thorax. Scutum overlain with brown pubescence, pale grey pubescent laterally and as a pale, dorsocentral stripe which tapers posteriorly; spot of pale pubescence present at transverse suture; matte black pubescence on posterior half of scutum; scutum covered with fine, dark setae, pale along notopleural margin; scutal macrosetae black; scutellum overlain with matte black pubescence, admixed with dark, elongate setae; pleuron and coxae dark, overlain with silver pubescence except on anepisternum, anepimeron and katatergite; numerous elongate, pale setae on proepisternum, anepisternum, katatergite, dorsal section of katepisternum and anterior surface of coxae; legs brown, fore and mid femora dark yellow on anterior surfaces; dense pale setae on posterior surfaces of femora; wing hyaline with translucent brown spots in anterior cubital cell $\left(c u a_{1}\right)$ and cell $r_{5}$; venation brown; haltere stem brown, knob cream; scutal chaetotaxy (pairs): np, 4; sa, 1; pa, 1; dc, 1; sc, 1.

Abdomen. Glossy dark brown; dorsomedially overlain with bronze-brown pubescence admixed with short, dark setae; elongate, pale setae laterally on all tergites; tergite 1 covered with grey pubescence; posterior margins of tergites $2-4$ with silver velutum plaques of dense pubescence; terminalia red-brown with pale setae.

Male genitalia. Epandrium bulbous anteriorly, posterior margin emarginate medially, appearing incised (Fig. 6A); cercus elongate, quadrangular; tergite 8 medially emarginate; gonocoxite appearing wedge-shaped in profile (Fig. 6B); gonocoxal process barely evident; inner gonocoxal process broadly spatulate, equal length to gonostylus; ventral lobe spatulate, projecting dorsomedially (Fig. 6C); medial atrium present; gonocoxal apodeme greatly elongate, much longer than gonocoxites; hypandrium broad with distinctive posterolateral processes covered with dark setae; sternite 8 sub-triangular; aedeagus with distiphallus greatly elongate, slightly recurved dorsally along length; dorsal apodeme of parameral sheath slender, ' $T$ '-shaped, attached to membranous hypoproct; lateral ejaculatory apodeme and ejaculatory apodeme greatly enlarged; arms of ven- 
tral apodeme of aedeagal sheath relatively large.

Female. Body length: $9.0 \mathrm{~mm}$.

Similar to male except: Frons wider than ocellar tubercle at narrowest point, frons not as striated and more sparse pubescence; scutum with matte black pubescence anterolaterally, extending posteriorly to transverse suture a stripe; metallic grey-silver pubescent patch medially on scutum; setae on thorax, legs and abdomen shorter, often darker than in male; abdomen without silver velutum plaques.
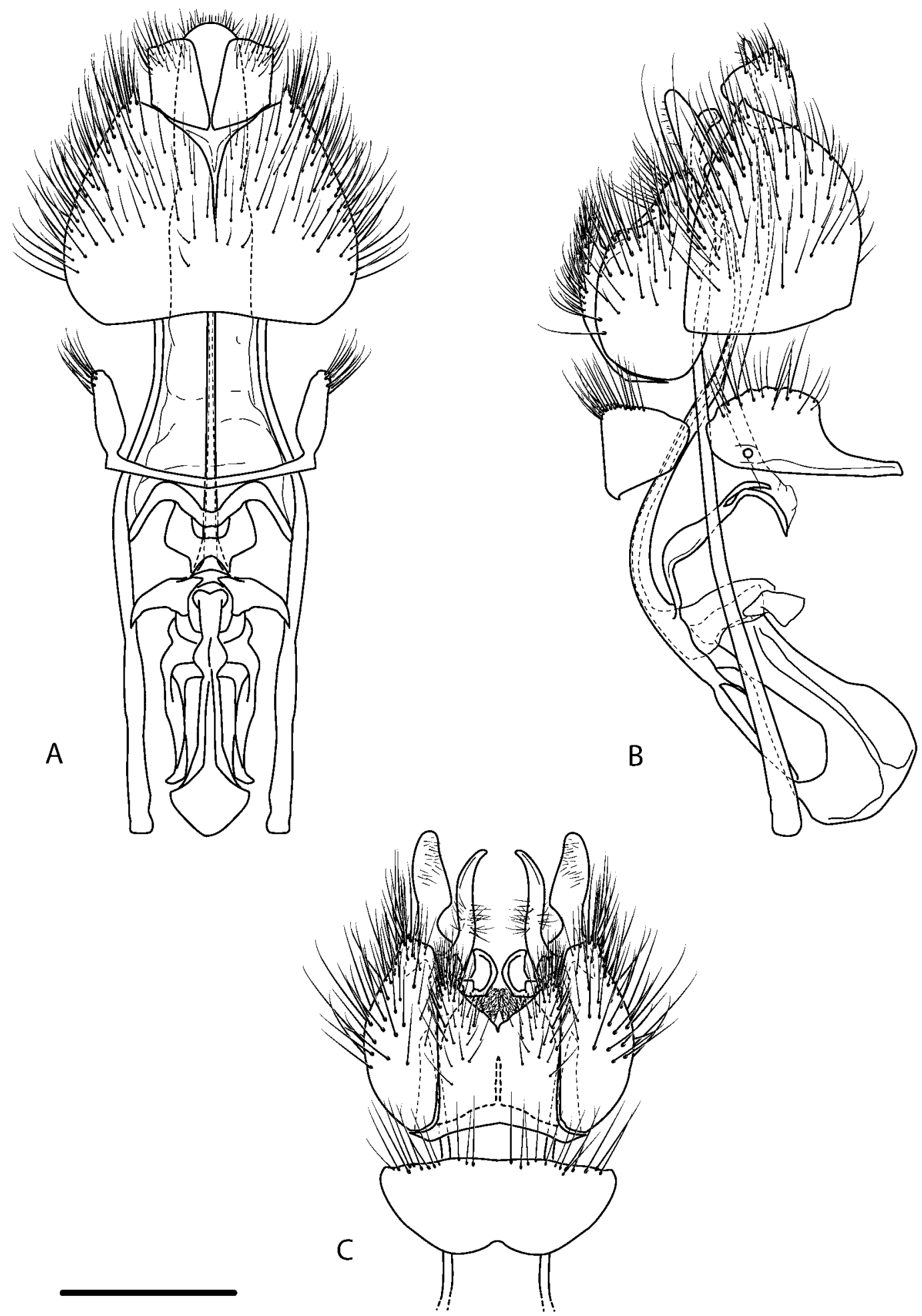

FIGURE 6. Bonjeania lambkinae sp. nov., male genitalia: A, dorsal view; B, same, lateral view; C, gonocoxites and sternite 8 , ventral view. Scale line $=0.5 \mathrm{~mm}$. 
Female genitalia. Genitalia not dissected.

Etymology. The specific epithet is a matronym in honour of Christine L. Lambkin, who collected the specimens on which this description is based.

Comments. This species is represented by single male and female specimens. The markings on the female scutum are very distinctive and while overlapping with the male, they are more ornate and complex. Consequently, the female examined here is tentatively identified as B. lambkinae sp. nov. While most of the body pattern and colouration is concordant between the male and female specimens, the large differences in scutal pattern could also suggest that the female is not conspecific with the male type.

\section{Bonjeania webbi sp. nov.}

(Figure 7)

Holotype male, AUSTRALIA: QUEENSLAND: Carnarvon NP, Mt. Moffatt Summit, 1097m, 2503'35'S, 14802’38”E, 20.i.1998, S.L. Winterton, J.\&A. Skevington (MEI 91438) (ANIC).

Paratypes, AUSTRALIA: QUEENSLAND: male, same data as holotype, 27.xi.1997, J.H. Skevington, C.L. Lambkin (MEI 91439) (QDPI); female, Carnarvon NP, Mt. Moffatt Section, Malaise trap near Mt. Mt. Moffatt Section, 19-23.i.1998, S.L. Winterton, J.\&A. Skevington (MEI 91441) (UQIC); female, Carnarvon NP, Mt. Moffatt Section, Mt. Moffatt Rd., dry creek, 2503'52’S, 14801'00”E, 2.xii.1997, J.H. Skevington, C.L. Lambkin, S. Evans, Malaise (MEI 91443) (INHS); male, Carnarvon NP, Mt. Moffatt Section, W Branch Maranoa R. (site 16), 2508'22”S, 14750'37'E, 660m amsl, 26.xi.1995, M.E. Irwin, S.D. Gaimari, ex. 9m Fock's Malaise trap (MEI 31364) (ANIC). NEW SOUTH WALES: female, Warrumbungle NP, Buckleys Ck. 1.5 km NE Blackman Camp, 14.i.1994, M.E. Irwin, D.K. Yeates, Malaise trap (MEI 26199) (MEIC); female, Warrumbungle NP, Browns Ck. 2.5 km N Woolshed, 15.i.1994, M.E. Irwin, D.K. Yeates Malaise trap (MEI 26201) (MEIC); female, [Warrumbungle NP, Buckleys Ck.] $1.5 \mathrm{~km} \mathrm{~N}$ Camp Blackman, 14.i.1994, M.E. Irwin, D.K. Yeates, Malaise trap (MEI 26200) (MEIC); female, Warrumbungle NP, Buckleys Ck. 1.5 km NE Blackman Camp, 17.xii.1995, M.E. Irwin (MEI 51082) (ANIC); female, Warrumbungle NP, Browns Ck. 2.5 km N Woolshed, 16.xii.1995, M.E. Irwin, Malaise trap (MEI 35711) (ANIC).

Diagnosis. Lower frons and face protruding anteriorly; wing costal margin orange infuscate; scutum bright orange with black, medial stripe; abdomen orange with dark stripe on sternites; male genitalia with epandrium much shorter along midline than width; aedeagus and gonocoxal apodemes elongate; ejaculatory apodemes not enlarged; distiphallus broadly recurved and thickened distally, hypandrium narrow, band-like.

Description. Male. Body length: 8.0-9.0 mm.

Head. Frons slightly narrower than ocellar tubercle at narrowest point; antennal base positioned low on frons (Fig. 7A); upper frons flat, lower frons and face protruding anteroventrally; frons and face smooth, glossy black; erect, pale setae sparsely distributed on lower frons; grey pubescence on upper frons below ocellar tubercle; narrow strip of silver velutum laterally on frons along margin of eye, two patches on face beside and below antennal base; ocellar tubercle slightly raised, black with sparse, grey pubescence admixed with erect pale and dark setae posteriorly; occiput concave, black, overlain with grey pubescence; single row of relatively short, black, postocular setae; gena black with long, black setae, silver-white pubescence along margin of eye; palp and labellum brown with scattered, dark setae; antenna brown, length shorter than head; dark setae on scape and pedicel, scape glabrous laterally, flagellum with small patches of short, dark setae basally; flagellum wider and longer than scape and pedicel; scape glossy, pedicel and flagellum overlain with orangebrown pubescence.

Thorax. Scutum and scutellum bright orange with black medial stripe; stripe black, overlain with sparse white-grey pubescence, concentrated along lateral margins of stripe; scutum sparsely covered with elongate, erect, pale and dark setae; scutal macrosetae black; dorsal half of pleuron orange, ventral portion and legs 
glossy black, erect dark setae on proepisternum, anepisternum, katepisternum, katatergite and coxae, thicker patch of strong, dark setae on katatergite; legs with erect, elongate setae on fore and mid-femora; mid femur with 2-3 strong ventral bristles; fore and mid-tibia dark yellow-brown, hind tibia black; tarsi yellow-cream, individual tarsomeres brown distally; wing hyaline, translucent orange-brown infuscate basally along costal margin; venation yellow; haltere yellow-tan; scutal chaetotaxy (pairs): np, 4-6 [rarely 7]; sa, 1; pa, 1; dc, 2-3; sc, 1 .

Abdomen. Bright orange with conspicuous black stripe ventrally; tergites 1-3 brown medially; scattered erect, pale setae on all segments, longer laterally; ventral setae dark; terminalia dark.

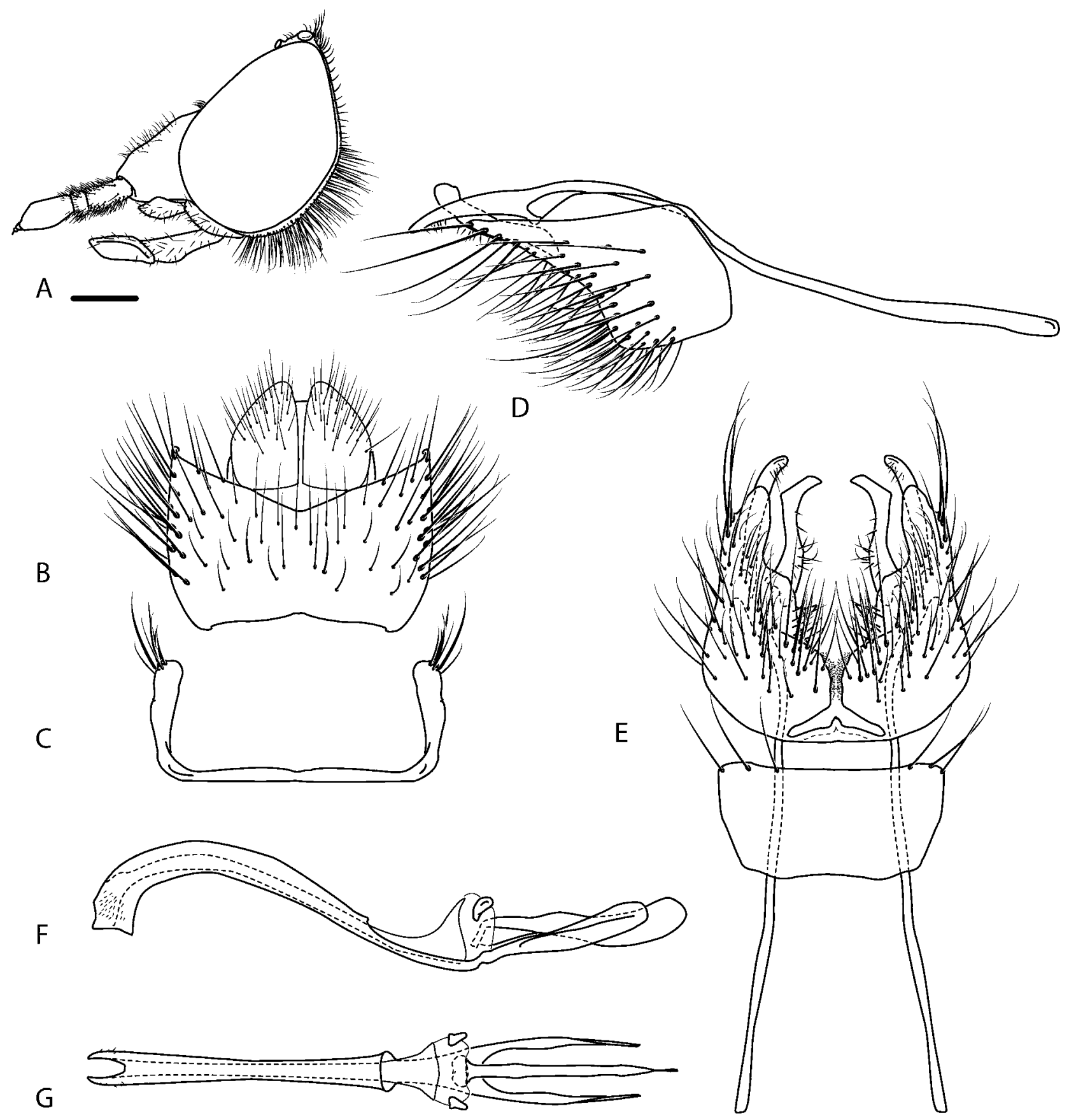

FIGURE 7. Bonjeania webbi sp. nov.: A, male head, lateral; male genitalia: B, epandrium, dorsal view; C, tergite 8, dorsal view; D, gonocoxite, lateral view; E, gonocoxites and sternite 8, ventral view; F, aedeagus, lateral view; G, same, dorsal view. Scale line $=0.5 \mathrm{~mm}$. 
Male genitalia. Epandrium much shorter than wide, deeply emarginate on both posterior and anterior margins, strong dark setae laterally (Fig. 7B); tergite 8 medially emarginate (Fig. 7C); gonocoxal process slightly shorter than gonostylus; inner gonocoxal process equal length to gonostylus (Figs 7D-E); gonostylus with patch of setae basally, projecting dorsally; gonocoxal apodeme $c a$. 2x length of gonocoxite; ventral lobe small, angular; medial atrium large, pubescence anteriorly along medial margin of gonocoxite; hypandrium reduced; sternite 8 broadly quadrangular (Fig. 7E); aedeagus elongate, distiphallus with broad ventral curve, compressed laterally, broad apically with minute spines (Figs 7F-G); lateral ejaculatory apodeme relatively small in size; ejaculatory apodeme narrow, elongate; arms of ventral apodeme of aedeagal sheath relatively narrow and elongate.

Female. Body length: 7.0-9.5 mm.

Similar to male except: Frons wider than ocellar tubercle at narrowest point, frons with strip of silver velutum along entire frontal eye margin antennal base orange laterally; setae on thorax, legs and abdomen shorter, often darker than in male.

Female genitalia. Spermathecal sac rounded, single lobe, spermathecal sac duct relatively long, without sclerotised band; single membranous, round spermatheca; spermathecal duct joined to spermathecal sac duct proximal to base of spermathecal sac; accessory gland elongate, relatively small.

Etymology. The specific epithet is a patronym in honour of Donald W. Webb, a prolific New World therevid taxonomist.

Comments. Bonjeania webbi sp. nov. is most closely related to B. bapsis sp. nov. and has a similar distribution throughout inland central and southern Queensland to central New South Wales.

\section{Bonjeania zwicki sp. nov.}

(Figures 1,8)

Holotype male, AUSTRALIA: NEW SOUTH WALES: Budawang NP, $10 \mathrm{~km}$ on Western Distributor Rd., $\sim 350 \mathrm{~m}, 35^{\circ} 31^{\prime} 48.8^{\prime}$ 'S, 15001'42.7”'E, 18.xi.2004, mv lamp, A. Zwick (ANIC29 17728) (ANIC).

Diagnosis. Lower frons and face protruding anteriorly; body dark red with dark medial stripe on scutum; pleuron and anterior segments of abdomen with white-silver stripe of pubescence; anterior margin of wing infuscate; male genitalia with aedeagus and gonocoxal apodemes greatly elongate; ejaculatory apodemes greatly enlarged; lateral flanges of ejaculatory apodeme angled lateroventrally; posteroventral margin of gonocoxites dark pigmented.

Description. Male. Body length: $8.5 \mathrm{~mm}$.

Head. Frons glossy black, slightly narrower than ocellar tubercle at narrowest point; antennal base positioned low on frons; frons flat, slightly concave and rugose above antennal base; lower frons and face protruding anteriorly; pale setae sparsely distributed on frons, brown pubescence on upper frons, narrow strip of silver pubescence along eye margin; face overlain with silver pubescence; ocellar tubercle slightly raised, black with sparse, grey pubescence posteriorly admixed with short, dark setae; occiput concave, black, overlain with grey pubescence; single row of relatively short, black, postocular setae dorsally; gena black with long, pale setae; silver-white pubescence more dense along margin of eye; palp and labellum brown with scattered, dark setae; antenna dark brown, overlain with grey-brown pubescence; antennal length shorter than head; short, dark setae on scape and pedicel; flagellum with small patch of short, dark setae dorsally; flagellum longer than length of scape and pedicel combined.

Thorax. Scutum and scutellum dark red with broad, black medial stripe; narrow pale dorsocentral stripe along lateral margin of medial stripe; scutum sparsely covered grey pubescence admixed with erect, pale setae; setae darker laterally; scutal macrosetae black; pleuron dark red, pale elongate setae on proepisternum, anepisternum, katepisternum, katatergite and coxae; setae dark on katatergite; distinct white-silver stripe of 


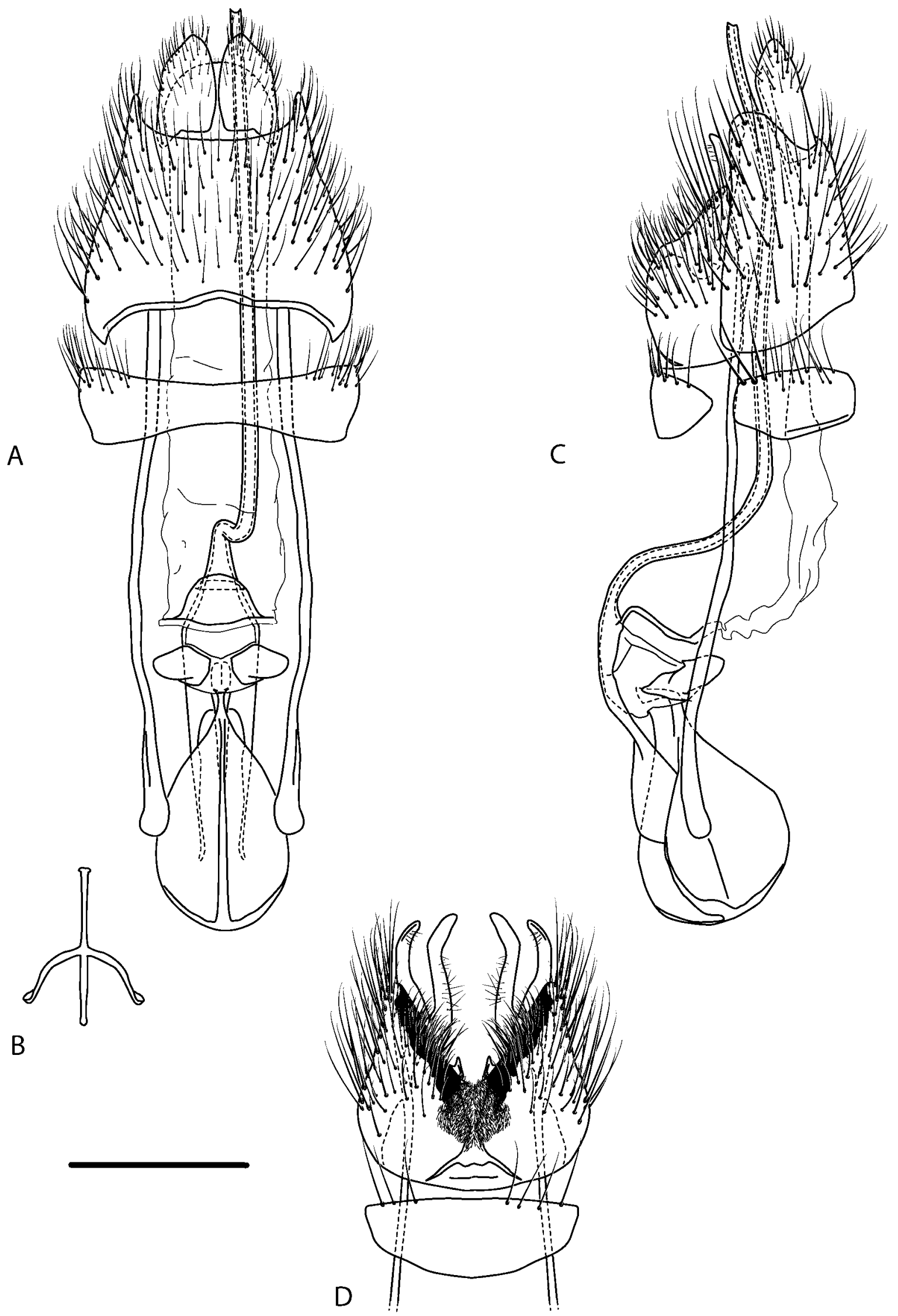

FIGURE 8. Bonjeania zwicki sp. nov., male genitalia: A, dorsal view; B, same, lateral view; C, ejaculatory apodeme, anterior (end on) view; D, gonocoxites and sternite 8 , ventral view. Scale line $=0.5 \mathrm{~mm}$. 
pubescence on proepisternum, katepisternum, katepimeron, meron and metanepisternum; coxae dark red, overlain with sparse, grey pubescence admixed with pale setae; macrosetae on all coxae black; legs dark red; pale setae on femora; tibia with black macrosetae; dense yellow pubescence on ventral surface of fore tibia; fore tarsus dark; mid and hind tarsi cream basally, dark red distally; wing hyaline, anterior margin slightly infuscate; pterostigma dark; venation light brown; haltere dark brown; scutal chaetotaxy (pairs): np, 5; sa, 1; pa, $1 ; \mathrm{dc}, 1 ; \mathrm{sc}, 1$.

Abdomen. Dark red, tergites 1-3 black medially, sternites 1-3 overlain with white-silver pubescence laterally; numerous scattered pale setae on all segments, setae longer laterally; setae on terminalia both pale and dark.

Male genitalia. Epandrium arched, trapezoid, medially slightly shorter than wide, emarginate on both posterior and anterior margins, posterolateral corners produced, rounded (Figs 8A, C); cercus quadrangular; tergite 8 slightly emarginate medially, elongate setae laterally; sternite 8 quadrangular; gonocoxite wedge-shaped in profile (Fig. 8C), elongate, dark setae ventrally and along posterior margin; posterior margin with distinctive dark pigmentation (Fig. 8D); medial atrium relatively small, overlain with velutum covered membrane; hypandrium small, fused to gonocoxites laterally; gonocoxal process much shorter than gonostylus; inner gonocoxal process equal length to gonostylus, spatulate apically; gonostylus recurved medially; ventral lobe narrow, directed dorsally; gonocoxal apodeme $\mathrm{ca}$. 3x length of gonocoxite; aedeagus elongate, distiphallus recurved dorsally proximal to ejaculatory apodeme; dorsal apodeme of parameral sheath poorly sclerotised, curved dorsally; arms of ventral apodeme of aedeagal sheath relatively broad apically, length approximately $1 / 2$ length of ejaculatory apodeme; lateral ejaculatory apodeme enlarged; ejaculatory apodeme greatly enlarged, flanges of apodeme cross-shaped in axial view, with horizontal flanges deflexed ventrally (Fig. 8B).

Female. Unknown.

Etymology. The specific epithet is a patronym in honour of Andreas Zwick, who collected this species.

Comments. The distinctive dark red colouration and white-silver pubescent lateral stripe of B. zwicki sp. nov. are diagnostic for this species. Bonjeania zwicki sp. nov. is known only from a single male specimen from New South Wales.

\section{Vomerina humbug gen. et sp. nov.}

(Figure 9)

Type species: Vomerina humbug sp. nov., by present designation.

Holotype male, AUSTRALIA: NEW SOUTH WALES: Tinderry Nature Reserve, Round Flat Fire Trail, 11.2 km E Michelago; across disused track in revegetation site, 19.xii.2004-16.i.2005, Malaise, 1186 m, C.L. Lambkin, N. Starick, 3543'08'S, 149¹7'26’'E (MEI 165137) (ANIC).

Paratypes, AUSTRALIA: NEW SOUTH WALES: 8 males, same data as holotype (MEI 165138, 165140-42, 165144-45) (ANIC), (MEI 165143, 165146) (QDPI).

Diagnosis. Lower frons and face protruding anteriorly; head and body black with distinct matte whitegrey stripe on pleuron and anterior part of abdomen; elongate velutum patches present on femora; wing cell $m_{3}$ closed; male genitalia with medial atrium and inner gonocoxal process lacking; ventral lobe plowshareshaped, projecting posteromedially with medial covering of velutum; dorsal apodeme of parameral sheath well sclerotised; ejaculatory apodeme and lateral ejaculatory apodeme short, not greatly elongated or enlarged; gonocoxal apodeme much shorter than gonocoxite length.

Description. Male. Body length: $7.0-8.0 \mathrm{~mm}$.

Head. Frons flat, rugose, much wider than ocellar tubercle at narrowest point, antennal base positioned low on frons; lower frons and face greatly protruding anteriorly (Fig. 9A), head glossy black; short, pale setae 
sparsely distributed on frons, medial stripe of silver pubescence on frons, around antennal bases and along margin of eye, single patch on face extending from margin of eye towards antennal base; ocellar tubercle flat, glossy black with sparse, short dark setae; occiput concave, black, overlain with dense grey pubescence; single row of relatively short, black postocular setae admixed with shorter setae; gena black, overlain with white pubescence admixed with white, elongate setae; palp and labellum brown-black with sparse, dark setae; antenna glossy black, slightly shorter than head; dark setae on scape and pedicel; scape equal to combined pedicel and flagellum length, slightly bulbous, smooth and glabrous, with silver pubescence on medial surface; flagellum conical shaped, narrower than scape.

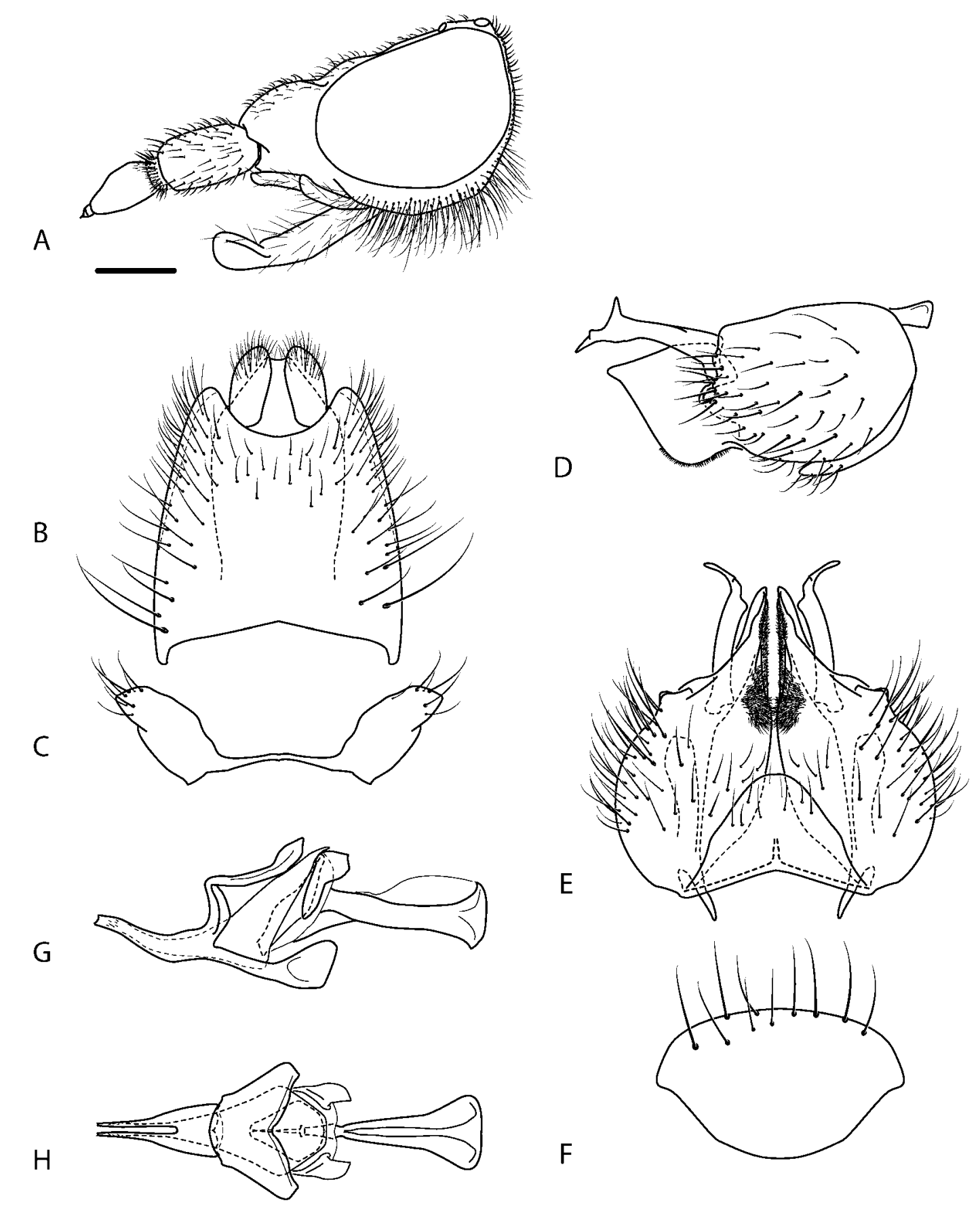

FIGURE 9. Vomerina humbug gen. et sp. nov.: A, male head, lateral view; male genitalia: B, epandrium, dorsal view; C, tergite 8, dorsal view; D, gonocoxite, lateral view; E, gonocoxites, ventral view; F, sternite 8, ventral view; G, aedeagus, lateral view; $\mathrm{H}$, same, dorsal view. Scale line $=0.5 \mathrm{~mm}$. 
Thorax. Black, scutum and scutellum overlain with grey-black pubescence admixed with relatively short, dark setae; scutum patterned thin dorsocentral and medial stripe of pale-grey pubescence, additional pale crescent-shaped markings sometimes present laterally; scutal macrosetae black; pleuron, sternum and coxae glossy black; distinctive broad stripe of grey pubescence along pleuron length; elongate pale setae on anepisternum, katatergite and coxae; legs black with pale setae of various lengths on femora; wing largely hyaline, translucent brown infuscate anteriorly along costal margin, fading to hyaline posteriorly; venation dark; haltere brown; scutal chaetotaxy (pairs): np, 5-6; sa, 1; pa, 1; dc, 1; sc, 1.

Abdomen. Glossy black, uniform scattered pale setae, longer laterally, white-grey pubescence laterally on sternites 1-3.

Male genitalia. Epandrium elongate, slightly tapered posteriorly (Fig. 9B), cercus ovate; tergite 8 emarginate medially (Fig. 9C); gonocoxite rounded in shape (Figs 9D-E), scattered short setae on ventral surface, denser laterally; gonocoxal processes absent; inner gonocoxal process completely absent; gonostylus narrow, apically processes projecting dorsally and laterally; gonocoxal apodeme very short; ventral lobe large, plowshare-shaped, projecting posteroventrally with velutinous pubescence on medial surface of ventral lobe and on ventral surface of gonocoxite; hypandrium relatively large, broadly triangular shaped with rounded corners, barely fused to gonocoxite laterally and overlapping gonocoxite posteriorly; sternite 8 sub-triangularshaped (Fig. 9F), setae along entire posterior margin; aedeagus relatively short, distiphallus tapered and upturned slightly towards apex (Figs 9G-H); dorsal apodeme of parameral sheath well sclerotised, ' $\mathrm{Y}$ 'shaped; ventral apodeme of parameral sheath relatively short, forked, arms broad apically; lateral ejaculatory apodeme well sclerotised and projecting anteriorly; ejaculatory apodeme length approximately equal to rest of aedeagus, well sclerotised.

Female. Unknown.

Etymology. The generic name is the feminine diminutive of Latin: vomer, plowshare; referring to the distinctive blade shaped ventral lobe of the male genitalia. The specific epithet describes the black and white striped colouration of the body that resembles a humbug, but is also an archaic term (etymology unknown) meaning 'hoax' or 'jest', referring to the strange male genitalia of this taxon.

Comments. Vomerina humbug gen. et sp. nov. is likely the sister taxon to Bonjeania based on external body shape. The male genitalia of this species are quite different in shape to any other therevid by lacking a medial atrium and inner gonocoxal process, the ventral lobe shape and having a well-sclerotised dorsal apodeme of the parameral sheath. The large, plowshare-shaped ventral lobes are distinctive and observable in undissected specimens. Dramatic reduction of inner gonocoxal processes is found in only one other Australian genus, Actenomeros Winterton \& Irwin (Winterton et al. 1999b), where the inner gonocoxal process is reduced but not completely absent as is found in this species. Vomerina humbug gen. et sp. nov. is known only from a series of males from Tinderry Nature Reserve, New South Wales.

\section{Acknowledgements}

Thank you to David Yeates (ANIC), Greg Daniels (University of Queensland) and Christine Lambkin (QMBA) for help with the loan of specimens. Thank you to Steve Gaimari, Martin Hauser, Donald Webb and Eric Fisher for reviewing the draft manuscript. This research was supported by the United States National Science Foundation under award DEB-0614213. Any opinions, findings and conclusions or recommendations expressed in this publication do not necessarily reflect the views of the National Science Foundation. 


\section{References}

Hauser, M. \& Irwin, M.E. (2003) The Nearctic Genus Ammonaios Irwin and Lyneborg 1981 (Diptera: Therevidae). Annals of the Entomological Society of America, 96, 738-765.

Hill, H.N. \& Winterton, S.L. (2004) Acraspisoides gen. nov. (Diptera: Therevidae: Agapophytinae): a new genus of stiletto-flies from Australia. Zootaxa, 414, 1-15.

Irwin, M.E. \& Lyneborg, L. (1981) Therevidae. Chapter 37. In: J.F. McAlpine, B.V. Peterson, G.E. Shewell, H.J. Teskey, J.R. Vockeroth \& D.M. Wood (coords.), Manual of Nearctic Diptera, Volume 1, pp. 513-523, Monograph No. 27, Research Branch, Agriculture Canada, 1-674 pages.

Irwin, M.E. \& Lyneborg, L. (1989) Family Therevidae. In: N.L. Evenhuis (ed.), Catalog of Diptera of the Australasian and Oceanian Regions, pp 353-358, Bishop Museum Special Publication, 86, 1-1155.

Kampmeier, G.E., Irwin, M.E. \& Algmin, K. (2004) Mandala 5.3: A database system for systematics \& biodiversity studies. Diptera Data Dissemination Disk II (CD-ROM). North American Dipterists Society.

Macquart, J.M. (1850) Diptères exotiques nouveaux ou peu connus. 4. ${ }^{e}$ supplement. Mémoirs de la Société Royale des Sciences, de l'Agriculture et des Arts, de Lille, 1849, 309-479.

Mann, J.S. (1929) Revisional notes on Australian Therevidae. Part 2. Australian Zoologist, 6, 17-49.

McAlpine, J.F. (1981) Morphology and Terminology - Adults. In: J.F. McAlpine, B.V. Peterson, G.E. Shewell, H.J. Teskey, J.R. Vockeroth \& D.M. Wood (coords.) Manual of Nearctic Diptera, Volume 1, pp. 9-63, Monograph No. 27, Research Branch, Agriculture Canada, Ottawa, 1-674 pages.

Nichols, S.W. (ed.) (1989) The Torre-Bueno glossary of entomology: revised edition. New York Entomological Society. $840 \mathrm{pp}$.

White, A. (1915) The Diptera-Brachycera of Tasmania. Part II. Families Tabanidae and Therevidae. Papers and Proceedings of the Royal Society of Tasmania, 1915, 2-60.

Wiman, C. (1910) Ein paar Labyrinthodontenreste aus der Trias Spitzbergens. Bulletin of the Geological Institution of the University of Upsala, 9, 36-40.

Winterton, S.L. (2006) New species of Eupsilocephala Kröber from Australia (Diptera: Therevidae). Zootaxa, 1372, 1725.

Winterton, S.L., Irwin, M.E. \& Yeates, D.K. (1999a) Systematics of Nanexila gen. nov. (Diptera: Therevidae) from Australia. Invertebrate Taxonomy, 13, 237-308.

Winterton S.L., Irwin, M.E. \& Yeates, D.K. (1999b) Phylogenetic revision of the Taenogera Kröber genus-group (Diptera: Therevidae), with descriptions of two new genera. Australian Journal of Entomology, 38, $274-290$.

Winterton, S.L., Skevington, J.H., Irwin, M.E. \& Yeates, D.K. (2000) Phylogenetic revision of Bonjeania Irwin \& Lyneborg (Diptera: Therevidae). Systematic Entomology, 25, 295-324.

Winterton, S.L., Yang, L., Wiegmann, B.M. \& Yeates, D.K. (2001) Phylogenetic revision of Agapophytinae subf. n. (Diptera: Therevidae) based on molecular and morphological evidence. Systematic Entomology, 26, 173-211. 